\title{
DIRECT-HYDROGEN-FUELED PROTON-EXCHANGE-MEMBRANE FUEL CELL SYSTEM FOR TRANSPORTATION APPLICATIONS
}

\section{CONCEPTUAL VEHICLE DESIGN REPORT BATTERY AUGMENTED FUEL CELL POWERTRAIN VEHICLE}

CONTRACT NO. DE-AC02-94CE50389

Prepared by:

D. Oei, J.A. Adams, A.A. Kinnelly, G.H. Purnell, R.I. Sims, M.S. Sulek, and D.A. Wernette Ford Motor Company

Dearborn, Ml 48121

B. James, F. Lomax, G. Baum, C. E. Thomas, and I. Kuhn

Directed Technologies, Inc.

Arlington, VA 22203

JULY 1997

DISTRUSUTION OF TMIS

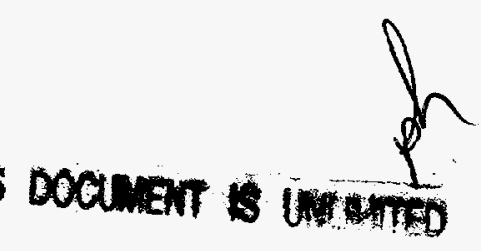

PREPARED FOR:

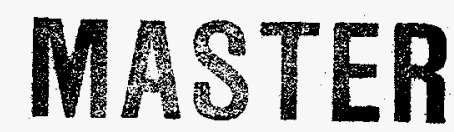

\section{U.S. DEPARTMENT OF ENERGY}

OFFICE OF TRANSPORTATION TECHNOLOGIES

PREPARED BY:

FORD MOTOR COMPANY

DEARBORN, MI 48121 


\section{FOREWORD}

This report documents a portion of the results of the project entitled "Direct-Hydrogen-Fueled Proton-Exchange-Membrane Fuel Cell System for Transportation Applications" performed by Ford Motor Company, under contract DE-AC02-94CE50389. The project objective was to design, fabricate, and test a 50-kW direct hydrogen fueled proton exchange membrane (PEM) fuel cell system including onboard hydrogen storage, efficient lightweight fuel cell, gas management system, and complete system controls that can be economically mass produced and comply with all safety, environmental, and consumer requirements for vehicle applications for the 21 st century. Specifically, this report presents conceptual designs for a batteryaugmented fuel cell-powered vehicle based on three different vehicle classes, namely, small car, mid-size car, and full-size van.

Dr. Djong-Gie Oei, project manager at Ford, prepared the report with contributions from Ford staff, namely, James Adams, Alan Kinnelly, Georgianna Purnell, Ron Sims, Mark Sulek, and David Wernette. Brian James, Franklin Lomax, George Baum, C. E. (Sandy) Thomas, and Ira Kuhn, all from Directed Technologies, Inc., also contributed to the report.

This work was funded by the U.S. Department of Energy (DOE), Energy Efficiency and Renewable Energy, Office of Transportation Technologies, Office of Advanced Automotive Technologies. Project and technical management was provided by Mr. Steven Chalk, and Ms. Donna Lee of DOE's Office of Advanced Automotive Technologies with technical oversight and advice provided by Dr. Walter Podolski and Dr. James Miller of Argonne National Laboratory. Mr. Bradford Bates, Manager of the Alternative Power Source Technology Department at Ford Motor Company was responsible for this program. 


\section{DISCLAIMER}

This report was prepared as an account of work sponsored by an agency of the United States Government. Neither the United States Government nor any agency thereof, nor any of their employees, make any warranty, express or implied, or assumes any legal liability or responsibility for the accuracy, completeness, or usefulness of any information, apparatus, product, or process disclosed, or represents that its use would not infringe privately owned rights. Reference herein to any specific commercial product, process, or service by trade name, trademark, manufacturer, or otherwise does not necessarily constitute or imply its endorsement, recommendation, or favoring by the United States Government or any agency thereof. The views and opinions of authors expressed herein do not necessarily state or reflect those of the United States Government or any agency thereof. 


\section{DISCLAIMER}

Portions of this document may be illegible electronic image products. Images are produced from the best available original document. 
Table of Contents

$\begin{array}{lr}\text { Abstract } & 2\end{array}$

1.0 Executive Summary $\quad 3$

$\begin{array}{ll}1.1 \text { Introduction } & 3\end{array}$

1.2 Vehicle Requirements and Battery Augmented Fuel Cell Powertrain 3

1.3 Conceptual Propulsion System Vehicle Package Design 3

1.4 Fuel Cell Power System Cost Study 4

$\begin{array}{ll}2.0 \text { Introduction } & 5\end{array}$

2.1 Goals and Objectives of Report

2.2 Ford Team and Tasks $\quad 5$

3.0 Vehicle Requirements and Battery Augmented Fuel Cell Powertrain $\quad 7$

$\begin{array}{ll}\text { 3.1 Vehicle Type and Performance Specification } & 7\end{array}$

$\begin{array}{ll}\text { 3.2 Battery Augmented Fuel Cell Power Requirements } & 7\end{array}$

4.0 Conceptual Propulsion System Vehicle Package Design 20

$\begin{array}{ll}4.1 \text { Aspire } & 20\end{array}$

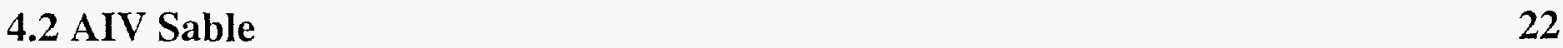

4.3 E-150 Econoline Van $\quad 24$

5.0 Fuel Cell System Cost Competitiveness 26

$\begin{array}{ll}5.1 \text { Costing Approach } & 26\end{array}$

5.2 Fuel Cell Power System Options

5.3 Cost Modeling Assumptions $\quad 32$

5.4 Preliminary PEM Power System Cost Estimates 37

6.0 Conclusions and Recommendations 42

$\begin{array}{ll}\text { References } & 43\end{array}$ 


\begin{abstract}
In partial fulfillment of the U.S. Department of Energy Contract No. DE-AC02-94CE50389, "Direct Hydrogen-Fueled Proton-Exchange-Membrane (PEM) Fuel Cell System for Transportation Applications", this conceptual vehicle design report addresses the design and packaging of battery augmented fuel cell powertrain vehicles. This report supplements the "Conceptual Vehicle Design Report - Pure Fuel Cell Powertrain Vehicle" and includes a cost study of the fuel cell power system. The three classes of vehicles considered in this design and packaging exercise are the same vehicle classes that were studied in the previous report: the Aspire, representing the small vehicle class; the AIV (Aluminum Intensive Vehicle) Sable, representing the mid-size vehicle; and the E-150 Econoline, representing the van-size class. A preliminary PEM fuel cell power system manufacturing cost study is also presented.
\end{abstract}

As in the case of the previous report concerning the "Pure Fuel Cell Powertrain Vehicle", the same assumptions are made for the fuel cell power system. These assumptions are fuel cell system power densities of $0.33 \mathrm{~kW} / \mathrm{kg}$ and $0.33 \mathrm{~kW} / 1$, platinum catalyst loading of less than or equal to $0.25 \mathrm{mg} / \mathrm{cm}^{2}$ total, and hydrogen tanks containing compressed gaseous hydrogen under $340 \mathrm{~atm}$ (5000 psia) pressure. The batteries considered for power augmentation of the fuel cell vehicle are based on the Ford Hybrid Electric Vehicle (HEV) program. These are state-of-the-art high power lead acid batteries with power densities ranging from $0.8 \mathrm{~kW} / \mathrm{kg}$ to $2 \mathrm{~kW} / \mathrm{kg}$.

The results reported here show that battery augmentation provides the fuel cell vehicle with a power source to meet instant high power demand for acceleration and start-up. Trade-offs between battery weight, volume and cost and fuel cell weight, volume and cost are carefully considered and discussed. Based on the assumptions made in this report, the packaging of the battery augmented fuel cell vehicle appears to be as feasible as the packaging of the pure fuel cell powered vehicle. 


\subsection{Executive Summary}

\subsection{Introduction}

The battery augmented fuel cell powertrain design is addressed in this report. This report is a follow-up of the previous "Conceptual Vehicle Design Report - Pure Fuel Cell Powertrain Vehicle" [1]. Statements and discussions in the previous executive summary are also applicable to this report. Ford Motor Company is actively engaged in research and development of hybrid electric vehicles. These programs involve the use of an internal combustion engine or a Diesel engine as a range extender for the battery powered electric vehicle. In the fuel cell powered vehicle program, the purpose of battery augmentation is to provide the electric vehicle with additional power for start-up and acceleration without significant energy storage. Trade-offs between battery weight, volume and cost and fuel cell weight, volume and cost are carefully considered and discussed. A preliminary study of the PEM fuel cell power system manufacturing cost is also presented.

\subsection{Vehicle Requirements and Battery Augmented Fuel Cell Powertrain}

The three vehicle types that are considered for the conceptual vehicle design are the Aspire, the Aluminum Intensive (AIV) Sable, and the E-150 Econoline van, representing the small, intermediate, and van size vehicles, respectively. In the conceptual vehicle design, customer expectations of vehicle performance, such as acceleration, throttle response, speed, range, gradeability, and start-up time are the most important parameters to be satisfied. Using the Fuel Cell Power System (FCPS) spreadsheet program developed by Directed Technologies, Inc. (DTI) and the Corporate Vehicle Simulation Program (CVSP), the following combinations of fuel cell and battery augmentation resulted for the three vehicles: a $40 \mathrm{~kW}$ fuel cell and $14 \mathrm{~kW}$ battery system for the Aspire, a $40 \mathrm{~kW}$ fuel cell and $45 \mathrm{~kW}$ battery for the AIV Sable, and a $70 \mathrm{~kW}$ fuel cell and $59 \mathrm{~kW}$ battery for the Econoline. These combinations of fuel cell and battery provide enough energy for at least four consecutive full power $0-96.5 \mathrm{~km} / \mathrm{h}(0-60 \mathrm{mph})$ accelerations. The corresponding electric motor powers are a $56 \mathrm{~kW}$ electric traction motor for the Aspire, a $90 \mathrm{~kW}$ electric motor for the AIV Sable, and a $138 \mathrm{~kW}$ motor for the Econoline.

The preliminary conclusions from this battery augmented fuel cell conceptual vehicle design, compared to the pure fuel cell vehicle, are as follows:

- better performance but limited time for peak power,

- added complexity (battery cooling, DC-DC converter, etc.),

- slightly higher vehicle weight for battery augmented power source,

- slightly lower efficiency.

\subsection{Conceptual Propulsion System Vehicle Package Design}

The packaging exercise for the three vehicles shows that the reduction in system volume from the $50 \mathrm{~kW}$ to the $40 \mathrm{~kW}$ fuel cell power system in the Aspire is about the same as for the $80 \mathrm{~kW}$ to the $40 \mathrm{~kW}$ fuel cell system for the AIV Sable. For the Econoline van, the change from the $125 \mathrm{~kW}$ to $70 \mathrm{~kW}$ fuel cell system resulted in a large system volume reduction. 
Just as in the case of the pure cell vehicle packaging, the vehicle packaging exercise shows that the Aspire loses rear passenger seat and trunk space, the AIV Sable relinquishes most of its trunk space, and only the Econoline van retains all seats and luggage space.

\subsection{Fuel Cell Power System Cost Study}

This cost study provides an estimate of the fuel cell power system cost and assesses its economic competitiveness with other automotive propulsion systems. The results presented in this report are preliminary capital cost estimates for the entire proton exchange membrane fuel cell power system only. Additional potential economic cost benefits, such as system life cycle cost and reduced emission of pollutants, are not incorporated in this study.

The preliminary cost estimate of the fuel cell stack ranges from $\$ 19 / \mathrm{kW}$ to a maximum of $\$ 47 / \mathrm{kW}$. These preliminary cost estimates are based on a broad range of proven generic component technologies and manufacturing approaches. Specific company-proprietary systems or techniques are not used in the cost study. Since the fuel cell stack is the key enabling technology of the fuel cell vehicle (FCV), it was chosen as the first system component for detailed study. Two fundamental manufacturing engineering concepts are applied in the cost study, namely the design for manufacturing and assembly (DFMA) and high manufacturing rate processes concepts. In addition, the detailed fuel cell stack estimate is based on the packaging of two fuel cell stacks into a single unit, designated as an Integrated Stack Package (ISP). The ISP contains 420 active cells of $350 \mathrm{~cm}^{2}$ active area with 210 cooling cells and produces $42 \mathrm{~kW}$ gross power near atmospheric pressure, and $70 \mathrm{~kW}$ gross power when operating at 3 atm (30 psig). The ISP design uses four different stack architectures and is constructed of three common materials, 316 stainless steel sheet metal, solid amorphous carbon, and carbon-polymer composite.

The preliminary total fuel cell power system cost estimates range from a minimum of $\$ 37 / \mathrm{kW}$ net to a maximum of $\$ 71 / \mathrm{kW}$ net. The total fuel cell power system cost estimates include all peripheral components costs, such as the compressor, air blower, electronic engine control (EEC) unit, radiator system, and hydrogen recirculation ejector. 


\subsection{Introduction}

\subsection{Goals and Objectives of Report}

The objectives of this report are to present the results of the battery augmented fuel cell vehicle design and packaging efforts and to analyze the feasibility and desirability of a battery augmented fuel cell powered vehicle. In addition, a preliminary cost study of the fuel cell power system required for automotive applications is presented.

The battery augmented fuel cell powertrain vehicle is an electric vehicle that has a fuel cell for its main powertrain and a set of batteries for power augmentation during start-up and acceleration. At present, practical experience of the response time for instant power demand during acceleration and start-up of a fuel cell engine is limited to the fuel cell powered bus [2]. This response time will be different for passenger cars as derived from the various corporate vehicle requirements. Practical experience with the battery powered electric cars indicates that the instant power demand for acceleration and start-up is readily accommodated by the battery power system. However, the battery powered electric vehicle has a limited range because of the limited amount of electrochemical energy that is stored between the battery electrodes. Hybridization of the battery powered electric vehicle, utilizing an internal combustion (IC) engine or other thermal engines, provides the system with a mileage range extender. However, a hybridized electric vehicle will not be a zero emission vehicle (ZEV), but may be an ultra low emission vehicle (ULEV). On the other hand, a direct hydrogen-fueled fuel cell electric vehicle, whether battery augmented or not, will remain a $\mathrm{ZEV}$ and will provide a range that is only a function of the amount of fuel that is carried onboard the vehicle.

Public acceptance of fuel cell powered vehicles depends on overcoming technical as well as cost barriers. Technical achievements, such as lowering the platinum catalyst loading and improving the membrane electrode assemblies, are also decisive factors in reducing the cost of fuel cell powertrain fabrication. A preliminary cost study of fuel cell powertrain manufacturing is included in this report.

\subsection{Ford Team and Tasks}

During Phase I of the "Direct Hydrogen-Fueled Proton-Exchange-Membrane (PEM) Fuel Cell System for Transportation Applications" contract, a final selection of fuel cell subcontractors was made based upon delivery of specific fuel cell stacks. The selected subcontractors for Phase II are Mechanical Technology Incorporated (MTI) of Albany, NY and International Fuel Cells (IFC) of South Windsor, CT. The task of the fuel cell subcontractors is to deliver, within 12 months of their contract award, a $50 \mathrm{~kW}$ net fuel cell power system having a gravimetric power density goal of $0.37 \mathrm{~kW} / \mathrm{kg}(6 \mathrm{lb} / \mathrm{kW})$ and Pt catalyst loading of less than or equal to $0.25 \mathrm{mg} / \mathrm{cm}^{2}$ total. 
Directed Technologies, Inc. (DTI) has been retained as a subcontractor to provide a cost study of the fuel cell power system as well as to study the hydrogen onboard storage methods and safety aspects. In addition DTI serves as consultant on various aspects of the fuel cell program.

Ford Motor Company is the major contractor and assumes responsibility for the overall program. Testing of the $50 \mathrm{~kW}$ fuel cell system will be carried out at the fuel cell subcontractor's premises, and after delivery to Ford, the fuel cell system will be tested at the Ford Research Laboratory. System integration of the fuel cell, simulation, and test bed evaluation will be conducted at the Ford research center. A final report will be issued at the end of the program. 


\subsection{Vehicle Type and Performance Specification}

The three vehicle types used in this report are the same as those utilized in the pure fuel cell vehicle design report. The three vehicle types are the Aspire, Aluminum Intensive Vehicle (AIV) Sable, and E-150 Econoline van, representing a small, intermediate and van size vehicle, respectively. Matching the fuel cell power system size with the three vehicle types is accomplished in the same manner as was done for the pure fuel cell vehicle. Short summaries are given in the following paragraphs.

As in the previous fuel cell vehicle design report, the Fuel Cell Power System (FCPS) spreadsheet program is used to project the characteristic performance of the fuel cell system (including all ancillaries). In addition to providing system dimensions for use in vehicle packaging, FCPS provides system weight and hydrogen consumption as a function of output power. The spreadsheet generates a manifold of such consumption vs. power performance curves at every $5 \mathrm{~kW}$ from 5 to $175 \mathrm{~kW}$ peak output power. These system performance curves and weights are used to characterize the fuel cell in the Corporate Vehicle Simulation Program (CVSP). The specific power, which the FCPS projects for the system, ranges from about $0.167 \mathrm{~kW} / \mathrm{kg}$ at $175 \mathrm{~kW}$ peak power to approximately $0.1 \mathrm{~kW} / \mathrm{kg}$ at $5 \mathrm{~kW}$. However, Ballard Power Systems (Vancouver, B.C.) has already demonstrated fuel cell systems with a gravimetric power density of approximately $0.33 \mathrm{~kW} / \mathrm{kg}$ and a power density of $0.3 \mathrm{~kW} / \mathrm{l}$. Therefore the original FCPS projected power and hydrogen consumption were used, but the system weight and volume were based on the Ballard demonstrated capabilities rather than the FCPS projection.

The approach used in setting performance targets is the same as would be employed in a typical internal combustion (IC) engine powered vehicle program. Experience with electric vehicle performance shows that extra attention is required to ensure highway performance acceptance. This is particularly important when a single speed transmission is used, as is the case here.

\subsection{Battery Augmented Fuel Cell Power Requirements}

Because of the cost of the fuel cell system and the size of its attendant hydrogen tanks, a more viable propulsion system may be a downsized fuel cell with an augmenting power source, such as a battery. The concept is to reduce the fuel cell power source to deliver the base or roadload vehicle power. The augmenting device would handle transient peak vehicle power requirements, such as accelerating, passing, hill climbing and so on. Selection of an augmenting device with energy acceptance capability will allow efficiency improvement from regenerative braking. Hydrogen supply requirements may be reduced if the overall vehicle system can be made more efficient. In addition, an augmenting device may be used or even required to compensate, at least partially, for any fuel cell power deficiencies during cold starts. 
Possible zero emission devices that could be used for power augmentation include batteries, ultracapacitors and flywheels. Near-term availability narrows the choice down to batteries. Recent advances in battery technology permit the battery selection to be narrowed to three stateof-the-art high power lead acid batteries available through the Ford Hybrid Electric Vehicle (HEV) program. Trade-off analyses among a number of issues (e.g., driveability, functionality, cost, complexity, packaging, weight, performance, range and energy efficiency) will be required to choose between a pure fuel cell powertrain vehicle or a battery augmented fuel cell vehicle. This report addresses only weight, performance, range, energy efficiency, and complexity of the propulsion system. The vehicle architecture of the battery augmented fuel cell vehicle is shown in Figure 1.

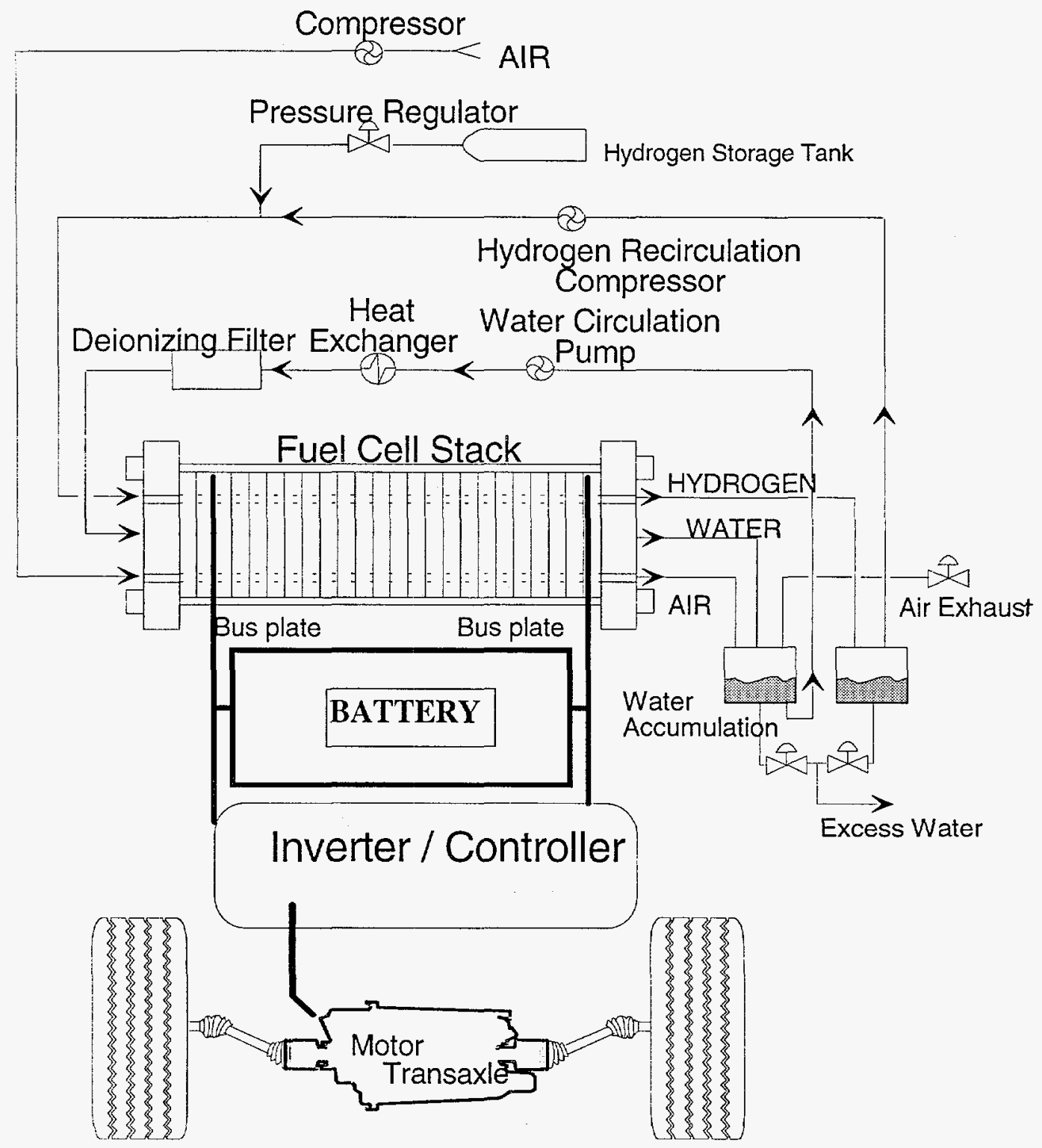

Figure 1 - Battery Augmented Fuel Cell Vehicle Architecture 
The fuel cell system power requirements were based on three typical automotive industry roadload criteria. The fuel cell system must provide sufficient power for the vehicle to satisfy the following grade and speed combinations:

- $0 \%$ grade at $137 \mathrm{~km} / \mathrm{h}(85 \mathrm{mph})$

- $3 \%$ grade at $105 \mathrm{~km} / \mathrm{h}(65 \mathrm{mph})$

- $7 \%$ grade at $80.5 \mathrm{~km} / \mathrm{h}(50 \mathrm{mph})$

As before, CVSP was used to model these conditions and determine the fuel cell power required for each vehicle size. Roadload engine power requirements for the three types of vehicles are shown in Figures 2, 3, and 4. The above three criteria resulted in similar engine power requirements for each vehicle. Selection of the most stringent of the three requirements for each vehicle gave the following results:
- Aspire
$40 \mathrm{~kW}$
- AIV Sable
$40 \mathrm{~kW}$
- E-150 Econoline
$70 \mathrm{~kW}$

The fact that the Aspire and AIV Sable have the same roadload requirements would appear to be unusual. However, inspection of the results reveals that the Aspire has only a relatively modest advantage in aerodynamic and tire rolling losses compared to the AIV Sable. These advantages are offset by increased motor and transmission losses because the Aspire's motor and transmission must operate at higher speeds due to its smaller tires, and thus incur greater losses.

Battery sizing methodology will be covered in greater detail in this section. For the present, the two sizing criteria are noted as follows:

- enough energy to provide at least four consecutive full power $0-96.5 \mathrm{~km} / \mathrm{h}$ $(0-60 \mathrm{mph})$ accelerations

- once the first criterion is met, add battery to the maximum allowable while not exceeding the vehicle weight class

The Ecostar electric drive system has a voltage operating range of 200 - 385 volts. In order to fully utilize the regenerative braking energy, the battery must provide a nominal open circuit voltage (OCV) of approximately 330 volts. This results in a single string of batteries to be built from approximately 160 cells in series. Of the three lead acid batteries considered, the Bolder battery was selected for this exercise. The Bolder battery has approximately a 4-5 to 1 advantage in volume and approximately a 4 to 1 weight advantage on a per string basis compared to the other two, and thus has more flexibility when adding battery strings within a given weight class. The ability to use more Bolder battery strings resulted in higher energy and improved energy efficiency. All three battery candidates provide more than enough power. In fact, an application specific design could trade-off power for high energy and employ a single string. 


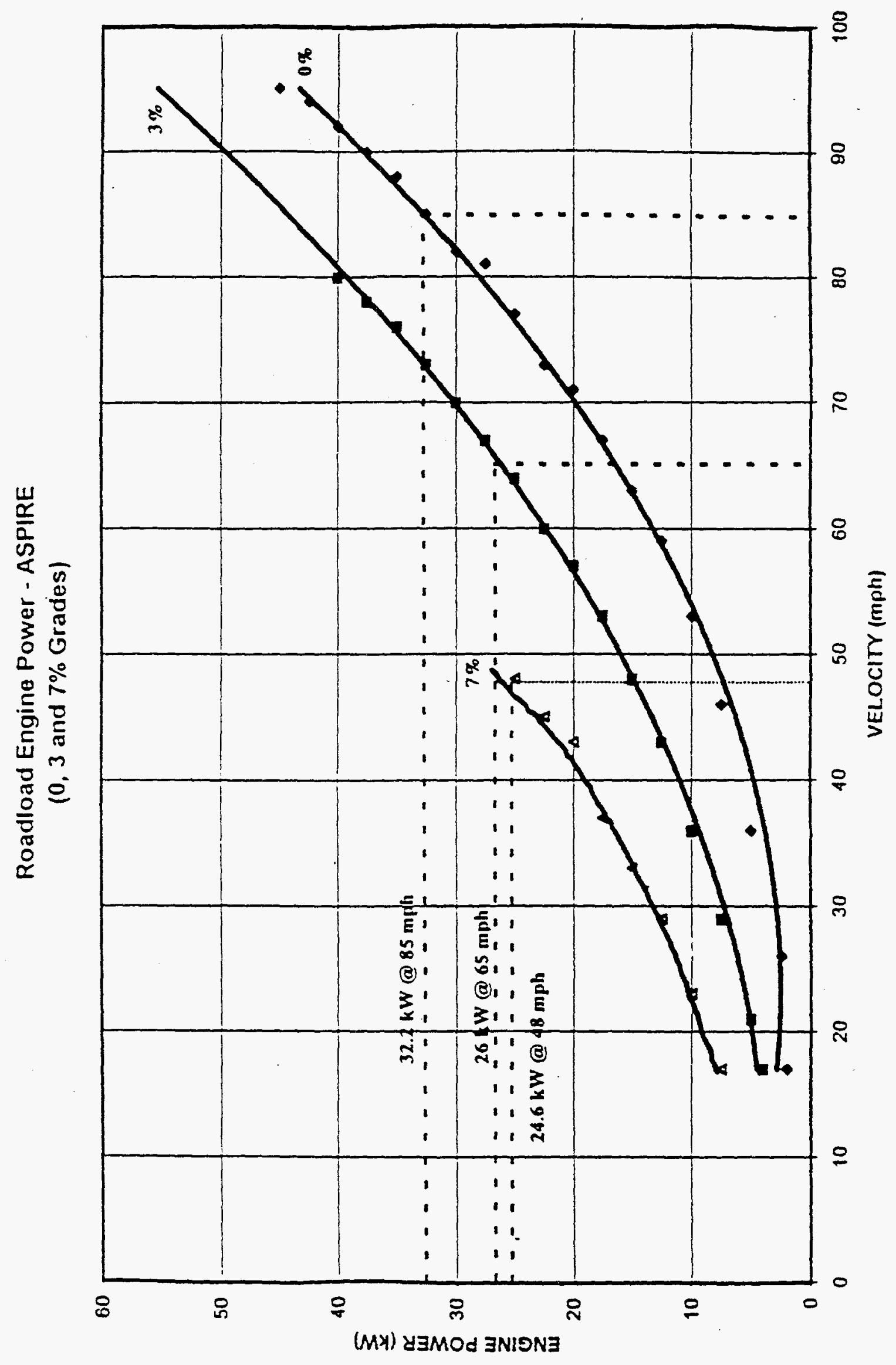

 


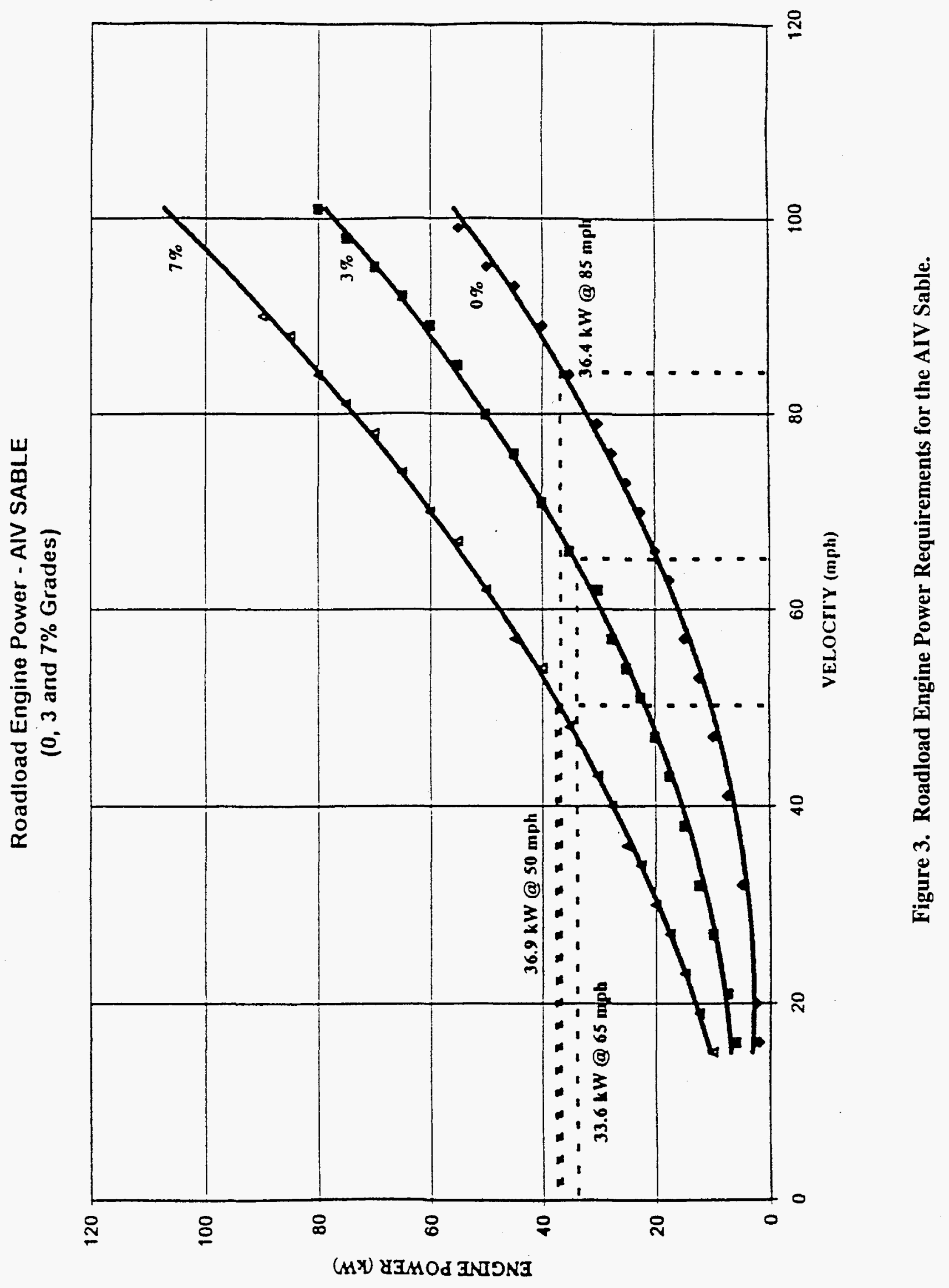




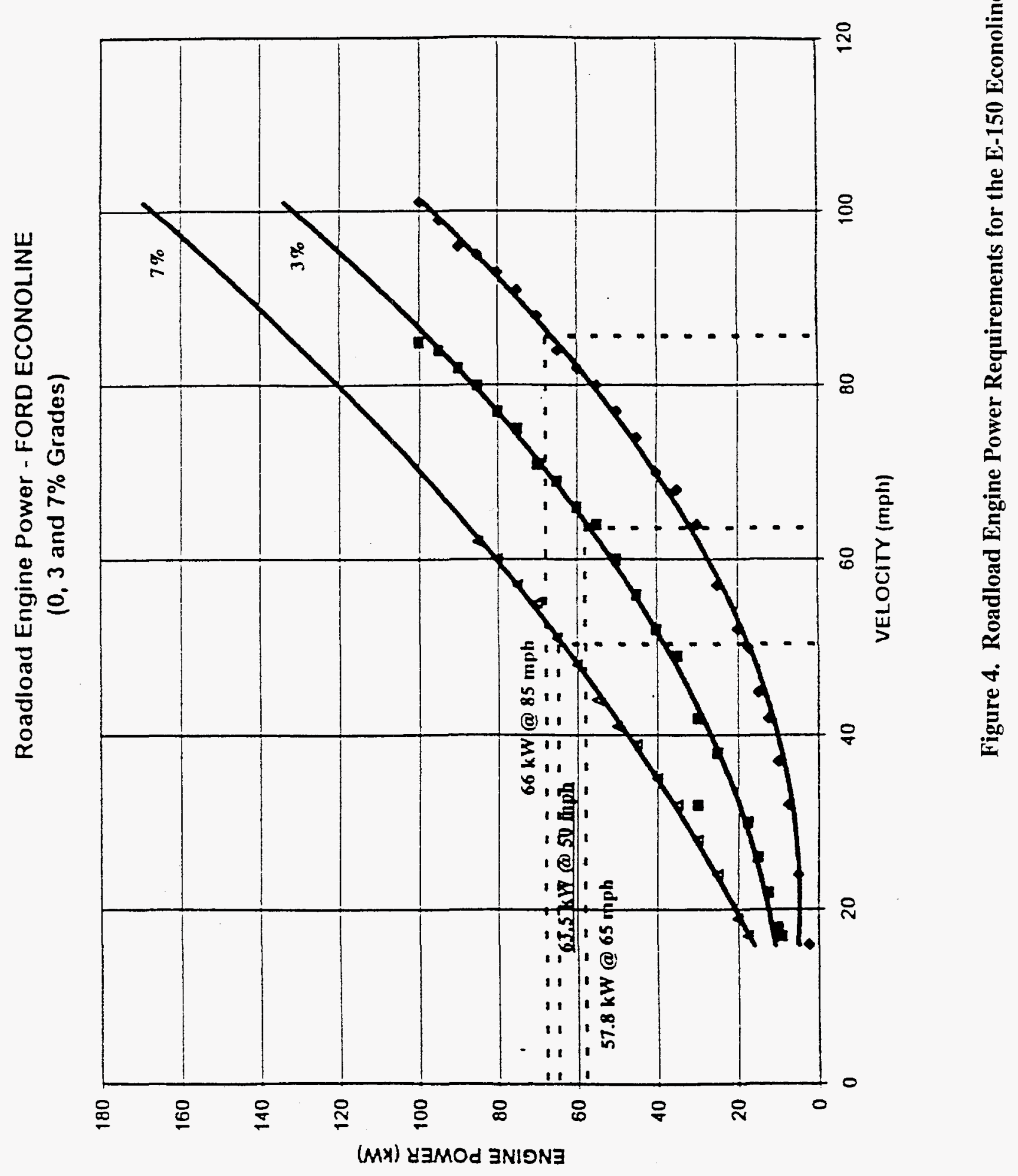


With Ford's current regenerative braking system, vehicle stability requires that increasingly more of the braking load be done by conventional mechanical brake system at increasing deceleration rates. For this vehicle, $100 \%$ of the braking wheel power is assumed to be available for regenerative braking. This is not unreasonable for the drive cycles involved if the new "series" regenerative braking system developed by Ford is assumed. However, this system has not been demonstrated in hardware.

Since the battery augmented fuel cell vehicle has two power sources available, a strategy is needed that controls how much power each source contributes under the complete range of vehicle operating conditions. For any given condition, the power required and the respective efficiency of the two sources will determine the best strategy. The on/off cycling of the main power device, namely the fuel cell, also needs to be monitored, so as to achieve an acceptable frequency. CVSP has a relatively flexible, generic strategy with most of the parameters involved being dependent on the storage device's (battery) state-of-charge (SOC). Only those parameters having a significant impact are discussed here. The parameter ranges were swept so as to obtain the best efficiency (i.e. greatest range) over the drive cycles. Three distinct operating modes were obtained:

- battery power with fuel cell assist

- fuel cell power with battery assist

- maximum fuel cell power to recharge battery (higher SOCs)

(mid-range SOCs)

(lower SOCs)

The specific SOC values for the above operating modes and the minimum fuel cell power levels for each vehicle are shown in Table 1.

Table 1

Battery Augmented Fuel Cell System Hybrid Operating Strategy

\begin{tabular}{|l|c|c|c|}
\hline & ASPIRE & AIV SABLE & $\begin{array}{c}\text { E-150 } \\
\text { ECONOLINE }\end{array}$ \\
\hline SOC1 & $45 \%$ & $55 \%$ & $90 \%$ \\
\hline SOC2 & $40 \%$ & $50 \%$ & $80 \%$ \\
\hline SOC3 & $40 \%$ & $40 \%$ & $45 \%$ \\
\hline SOC4 & $45 \%$ & $45 \%$ & $50 \%$ \\
\hline Minimum FC Power $(\mathrm{kW})$ & 0.3 & 0.3 & 1.0 \\
\hline
\end{tabular}

The higher SOC mode is initiated when the battery is recharged or regenerative braking has raised the SOC above SOC1. This mode continues until the SOC falls below SOC2. Battery power is used and the fuel cell is only used to assist when power demands exceed the battery's capability. For this and all modes, when the fuel cell is on, it is not allowed to drop below a set minimum power level. 
The mid-range SOC mode is the usual or normal mode that the vehicle operates in. It is initiated when the battery SOC falls below SOC2 or rises above SOC4. Fuel cell power is used, unless power demand requires battery assistance. The fuel cell is always on. During vehicle braking, any excess power is used to recharge the battery, up to the maximum the battery can accept. In general, it will continue as long as the battery energy losses from assisting the fuel cell approximately balance energy gains from regenerative braking.

The lower SOC mode is initiated when the battery SOC falls below SOC3 and ends when the SOC rises above SOC4. The fuel cell power is set so as to meet the driving requirements plus the maximum recharge power the battery can accept, up to maximum fuel cell power.

Implementation of this control strategy requires control of the power flow from the fuel cell and battery. Battery charge and discharge, for example, cannot be controlled without a means of controlling the respective battery and fuel cell voltages. To effect this, a DC-DC converter is assumed (i.e. modeled) between the battery and the main bus. A nominal $95 \%$ efficiency is assumed for the converter.

The augmented power source vehicle powertrain matching process was different from the one used for the pure fuel cell vehicles. Since the fuel cell power is set by roadload requirements, the battery size is varied to meet performance requirements. It is assumed that the test procedures for hybrid vehicles must also satisfy the current Environmental Protection Agency (EPA) emissions test weight procedure, as does the proposed Society of Automotive Engineers (SAE) hybrid procedure. Thus, the basic powertrain matching methodology employed involves adding battery strings up to the weight limit for a given class, and then selecting the lowest weight class that satisfies the following two criteria:

(1) The vehicle must meet the baseline vehicle performance targets as described in the previous report [1], at all battery SOCs. With the pure fuel cell vehicles, power and performance beyond the targets were avoided so as to help minimize component sizes. For augmented vehicles, this is not necessary. Once the second vehicle criterion (given below) is satisfied, the resultant battery has power well beyond that required for the performance targets. In fact, the power delivered has to be controlled by limiting the maximum output current.

(2) The vehicle must be able to perform the equivalent of four full power $0-96 \mathrm{~km} / \mathrm{h}$ $(0-60 \mathrm{mph})$ accelerations, which is about one continuous minute of full power. This somewhat arbitrary energy criteria was adopted from the DOE/MRI/Ford Hybrid Electric Vehicle Program. In mountainous regions, grade and speed combinations in excess of the roadload criteria can easily occur for more than one minute. This situation would result in depleting the battery energy, and, with only the fuel cell for propulsion, a significant reduction in performance would result. This and other customer usage patterns involving various combinations of speed, grade, vehicle load, and weather might result in unacceptable performance for this hybrid electric vehicle. A significant increase in the amount of battery would be required to remedy this, defeating the intent of this investigation. In this study, the power augmentation energy reserve is made as large as possible by adding battery strings up to the maximum allowable for a each vehicle weight class. 
In the pure fuel cell vehicles, the electric motor / inverter is oversized by $10 \%$ to help improve performance. Since the total power available is not a constraint and in fact increased by $8 \%$ (or less) for the augmented power versions, the electric motor / inverter size is unchanged. The final step in the powertrain matching / sizing again involves varying the overall drive ratio of the vehicle.

Table 2 shows the performance that results from the final powertrain matches for each vehicle.

Table 2

Battery Augmented Fuel Cell System Performance

\begin{tabular}{|c|cc|cc|cc|}
\hline Acceleration $(\mathrm{sec})$ & \multicolumn{2}{|c|}{ ASPIRE } & \multicolumn{2}{c|}{ AIV SABLE } & \multicolumn{2}{c|}{ ECONOLINE } \\
\hline $\mathrm{km} / \mathrm{h}(\mathrm{mph})$ & Target & Projection & Target & Projection & Target & Projection \\
\hline $\mathbf{0 - 9 6 . 5 ( 0 - 6 0 )}$ & 18.9 & 15.6 & 12.0 & 10.7 & 15.1 & 13.3 \\
\hline $8-32(5-20)$ & 3.2 & 2.3 & 2.0 & 2.0 & 2.2 & 1.9 \\
\hline $32-64(20-40)$ & 5.4 & 4.4 & 3.5 & 3.1 & 4.5 & 3.8 \\
\hline $64-96.5(40-60)$ & 9.3 & 8.2 & 5.6 & 5.2 & 7.4 & 6.9 \\
\hline $88.5-105(55-65)$ & 6.1 & 5.6 & 3.3 & 3.3 & 4.6 & 4.6 \\
\hline Maximum Speed, & & & & & & \\
\hline $\mathrm{km} / \mathrm{h}(\mathrm{mph})$ & $153(95)$ & $156(97)$ & $187.8(116)$ & $185(115)$ & $166(103)$ & $166(103)$ \\
\hline $\begin{array}{c}\text { Maximum } \\
\text { Gradeability }(\%)\end{array}$ & & & & & & \\
\hline From Standing Start & 30.2 & 31.3 & 37.0 & 34.4 & 30.2 & 33.9 \\
\hline $\begin{array}{c}\text { At } 88.5 \mathrm{~km} / \mathrm{h} \\
(55 \mathrm{mph})\end{array}$ & 10.6 & 10.6 & 16.0 & 17.1 & 11.9 & 12.5 \\
\hline
\end{tabular}

Each vehicle meets all performance targets. Highway performance feel is reflected in the $64-96.5 \mathrm{~km} / \mathrm{h}$ acceleration time, $88.5-105 \mathrm{~km} / \mathrm{h}$ acceleration time and the maximum gradeability at $88.5 \mathrm{~km} / \mathrm{h}$. For the Aspire, the maximum gradeability at $88.5 \mathrm{~km} / \mathrm{h}(55 \mathrm{mph})$ is the most demanding performance target, while the $88.5-105 \mathrm{~km} / \mathrm{h}(55-65 \mathrm{mph})$ acceleration time is the most demanding target for the AIV Sable and E-150 Econoline. The results indicate that $0-96 \mathrm{~km} / \mathrm{h}(0-60 \mathrm{mph})$ acceleration for these vehicles is $1-3$ seconds better than their respective production targets, and thus overall performance feel will be noticeably better.

Table 3 summarizes the resulting final battery augmented vehicle descriptions and contrasts them to the pure fuel cell vehicle characteristics. The total power available increases by 4,5 , and $4 \mathrm{~kW}$, respectively for the Aspire $(40+14=54$ vs. 50$)$, AIV Sable $(40+45=85$ vs. 80$)$, and Econoline $(70+59=129$ vs. 125). The overall drive ratio increased for all three battery augmented vehicles compared to the pure fuel cell powered vehicles. One way to understand this is that the increased power firmed up highway performance, thereby allowing the drive ratio to increase, to improve overall and launch performance. 
The performance test weight is unchanged for the AIV Sable and Econoline, while it increased by one weight class, or $57 \mathrm{~kg}(125 \mathrm{lb})$ for the Aspire. Three factors contribute to the fact that only the Aspire's weight class increased relative to its pure fuel cell version:

- its fuel cell system weight decrease was a smaller absolute and relative reduction from the pure fuel cell size

- it had a smaller weight cushion to the top of its weight class, resulting in less flexibility to add the required amount of battery

- the battery peripherals (cooling, etc.) are a larger percentage of the weight increase for the battery system.

Table 3

Battery Augmented Fuel Cell System

Powertrain Matching Results

\begin{tabular}{|l|c|c|c|}
\hline & ASPIRE & AIV SABLE & ECONOLINE \\
\hline Fuel Cell Power, kW (hp) & $40(54)$ & $40(54)$ & $70(94)$ \\
\hline Battery: & & & \\
\hline Number of cells/string & 150 & 150 & 150 \\
Number of strings & 4 & 5 & 12 \\
Bus Power, kW (hp) & $14(19)$ & $45(60)$ & $59(79)$ \\
Capacity, Ah & 5.6 & 7.0 & 16.8 \\
Estimated Energy, kWh & 1.34 & 1.83 & 3.40 \\
\hline Electric Motor/Inverter & & & \\
$\quad$ kW (hp) & $56(75)$ & $90(120)$ & $138(185)$ \\
\hline Overall Drive Ratio & 6.7 & 6.7 & 9.5 \\
\hline Performance Test Weight, kg (lb) & $1321(2912)$ & $1491(3287)$ & $2812(6200)$ \\
\hline Ref: Pure FC Vehicle & & & \\
FC Power, kW (hp) & $50(67)$ & $80(107)$ & $125(168)$ \\
Performance Test Weight, kg(lb) & $1264(2787)$ & $1491(3287)$ & $2812(6200)$ \\
\hline Overall Drive Ratio & 6.4 & 6.4 & 8.2 \\
\hline
\end{tabular}

Table 4 shows additional details of vehicle weights, driving ranges, and energy efficiencies. Weights for various vehicle components are provided along with the performance test weights. The range for each vehicle was determined for five different driving cycles. In order to achieve a $565 \mathrm{~km}$ (350 miles) range on the Federal Urban Driving Schedule (FUDS) cycle, the Aspire and AIV Sable require $0.4-0.5 \mathrm{~kg}(1 \mathrm{lb})$ less hydrogen than the pure fuel cell vehicle versions, while the Econoline requires $0.6 \mathrm{~kg}(1-2 \mathrm{lb})$ less hydrogen. Unless noted otherwise, the range effects presented below apply equally to all three vehicles. In comparing these results to the pure fuel cell vehicle results in Table 5, the range on the FUDS cycle is essentially unchanged. However, for all other cycles, there is a 29 to $77 \mathrm{~km}$ (18 to 48 miles) reduction in range for the battery augmented fuel cell vehicle compared to the pure fuel cell vehicle, equivalent to 6 to $14 \%$ reduction. Indeed, even with the amount of hydrogen used for the pure fuel cell vehicles, the range for the non-FUDS cycles are still, on average, slightly deficient. The reason for the range reduction with battery augmented fuel cell vehicles lies in fuel cell efficiency as a function of power requirement. 
Table 4

Battery Augmented Fuel Cell System

Weight, Range \& Energy Efficiency Results

Weight, kg (lb)

Fuel Cell

Battery

Electric Motor

Hydrogen (1)

Curb

Performance Test
ASPIRE AIV SABLE ECONOLINE

$\begin{array}{ccc}124(273) & 124(173) & 208(459) \\ 55(122) & 69(153) & 166(367) \\ 72(159) & 115(254) & 180(396) \\ 5.0(11) & 5.4(12) & 10.4(23) \\ 1186(2614) & 1355(2987) & 2397(5284) \\ 1321(2912) & 1491(3287) & 2812(6200)\end{array}$

$603(375) \quad 575(357)$

$600(373) \quad 595(370)$

$420(261) \quad 417(259)$

$465(289) \quad 462(287)$

385 (239) $389(243)$
$576(358)$

578 (359)

$423(263)$

459 (285)

378 (235)

\section{Energy Efficiency (2) on FUDS Cycle}

\begin{tabular}{llll}
\hline Average Vehicle Energy Rate $(\mathrm{kWh} / \mathrm{km})$ & $0.28(0.45)$ & $0.32(0.51)$ & $0.61(0.98)$ \\
Vehicle $\mathrm{km} / \mathrm{l}(\mathrm{mpg})$ & $32.2(75.7)$ & $28.0(65.8)$ & $14.6(34.4)$
\end{tabular}

(1) Required to provide at least $565 \mathrm{~km}$ (350 mi) range on the Federal Urban Driving Schedule (FUDS)

(2) Assuming 115,000 Btu per gallon of gasoline (LHV) and 51,532 Btu per pound of $\mathrm{H}_{2}$ (LHV)

Examination of fuel cell efficiency, in general, reveals that on a specific power basis, the smaller the device, the worse the efficiency. Thus the efficiency of the battery augmented vs. pure fuel cell vehicles is a balance between reduced fuel cell efficiency and the efficiency gained by regenerative braking.

Furthermore, the efficiency difference between a smaller vs. larger fuel cell increases from low to full power output. Thus, the higher the average power required for a drive cycle, the larger the efficiency disadvantage of a smaller fuel cell. Table 5 shows the average power required on the various drive cycles for the pure fuel cell vehicles. The battery augmented vehicles have a 7 to $10 \%$ efficiency advantage over the pure fuel cell versions on the relatively lower power FUDS cycle, but the pure fuel cell vehicles have increased efficiencies for the other cycles. This results in a design conflict: should the goal be best efficiency under regulatory test conditions like FUDS, or customer usage conditions like Ford Customer (ATDS) and Southern California Edison (SEC) commuter? 
Table 5

Pure Fuel Cell System

Powertrain Matching, Weight, Range \& Efficiency Results

Powertrain Parameters

Fuel Cell Power, kW (hp)

Electric Motor Power, kW (hp)

Overall Drive Ratio

Weights, kg (lb)

Fuel Cell

Electric Motor

Hydrogen Tanks w/o Hydrogen

Hydrogen (1)

Curb

Performance Test

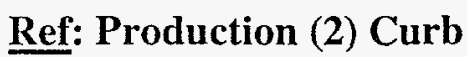

\section{ASPIRE}

$50(67)$

$56(75)$

6.4

150 (331)

72 (159)

$39(85)$

$5.4(12)$

1109 (2446)

1264 (2787)

941 (2075)

595 (370)

655(407)

456(277)

$518(322)$

428(266)

575 (357)

$29.3(68.9)$

$15.2(35.7)$
AIV SABLE

80 (107)

$90(120)$

6.4

235 (518)

115 (254)

42 (92)

$5.9(13)$

1348 (2972)

1491 (3287)

1168 (2575)

575 (357)

663(412)

457(284)

529(329)

449(279)

$621(386)$

26.1 (61.3)

10.3 (24.1)
ECONOLINE

125 (168)

138 (396)

8.2

360 (794)

180 (396)

78 (173)

11 (25)

2338 (5155)

2812 (6200)

2245 (4950)

$576(358)$

650(404)

452(281)

536(333)

439(273)

867 (539)

$13.6(32.0)$

$6.6(15.4)$

(1) Required to provide at least $565 \mathrm{~km}$ (350 mi) range on the Federal Urban Driving Schedule (FUDS)

(2) For AIV SABLE, base ICE-powered AIV

Comparison of the range results in Tables 4 and 5 show that the reduction in range of the battery augmented power vehicle of the Aspire was smaller than for the other two vehicles. Its average fuel cell efficiency was reduced the least, since it had a smaller absolute and relative reduction in fuel cell size. In fact, this relative efficiency advantage more than compensated for its increased weight.

It is clear that for a given application, a refined analysis is required to properly understand the efficiency trade-off balance noted above. In general, however, the larger the fuel cell the better with respect to efficiency. Also, a relatively aggressive regenerative braking capability is assumed in these analyses. Any reduction in that capability favors the efficiency of a pure fuel cell vehicle. 
In general, the comparison of battery augmented vs. pure fuel cell vehicles presented here suggests:

- the battery augmented vehicle will be more complex due to additional hardware, such as the battery, battery cooling, and DC-DC converter, and the need for a complex control strategy

- the battery augmented vehicle has better performance, but its peak power is available only for a limited amount of time

- the battery augmented vehicle weight should be similar to or slightly higher compared to a pure fuel cell vehicle

- energy efficiency and range will require careful analysis but will likely, overall, show a small advantage for the pure fuel cell vehicle.

These, of course, represent only part of the total analysis required to compare a battery augmented vs. pure fuel cell vehicle. However, this partial picture favors a pure fuel cell vehicle. 


\subsection{Conceptual Propulsion System Vehicle Package Design}

\subsection{Aspire}

In the battery augmented fuel cell vehicle packaging exercise, two minor changes were made to the overall package compared to that for the pure fuel cell vehicle. First, the fuel cell power system (fuel cell stack and peripheral components) total volume was decreased to 117 liters compared to 146 liters for the pure fuel cell. The decrease in volume was due to the reduction in the net fuel cell system power output requirement from $50 \mathrm{~kW}$ for the pure fuel cell vehicle to $40 \mathrm{~kW}$ for the battery augmented vehicle. The package placement remained the same with the stacks under the floor pan just ahead of the rear axle.

The second change to the overall package was the size and quantity of the hydrogen storage tanks. For the purpose of this study, the number of tanks was increased from two to three. The reason for this increase was due to the research and testing by Lawrence Livermore National Laboratory with a common $305 \mathrm{~mm}\left(12.0^{\prime \prime}\right)$ diameter tank. This size reduction increased the number of tanks, and for the purpose of this study was used in all three vehicles by only varying the length when necessary. The placement of the tanks remained the same. The only area of the vehicle that will accommodate them is behind the front seat occupants on the load floor.

The batteries for power augmentation are packaged under the front floor pan in the tunnel area between the front seat occupants. In this area, four strings of Johnson Controls Incorporated (JCI) Bolder 7.9 liter lead acid batteries are packaged.

The electric motor and peripherals are packaged in the existing engine compartment, along with the battery controllers and battery related components. Figure 5 shows the overall vehicle architecture. 


\section{ASPIRE AUGMENTED FUEL CELL PACKAGE}

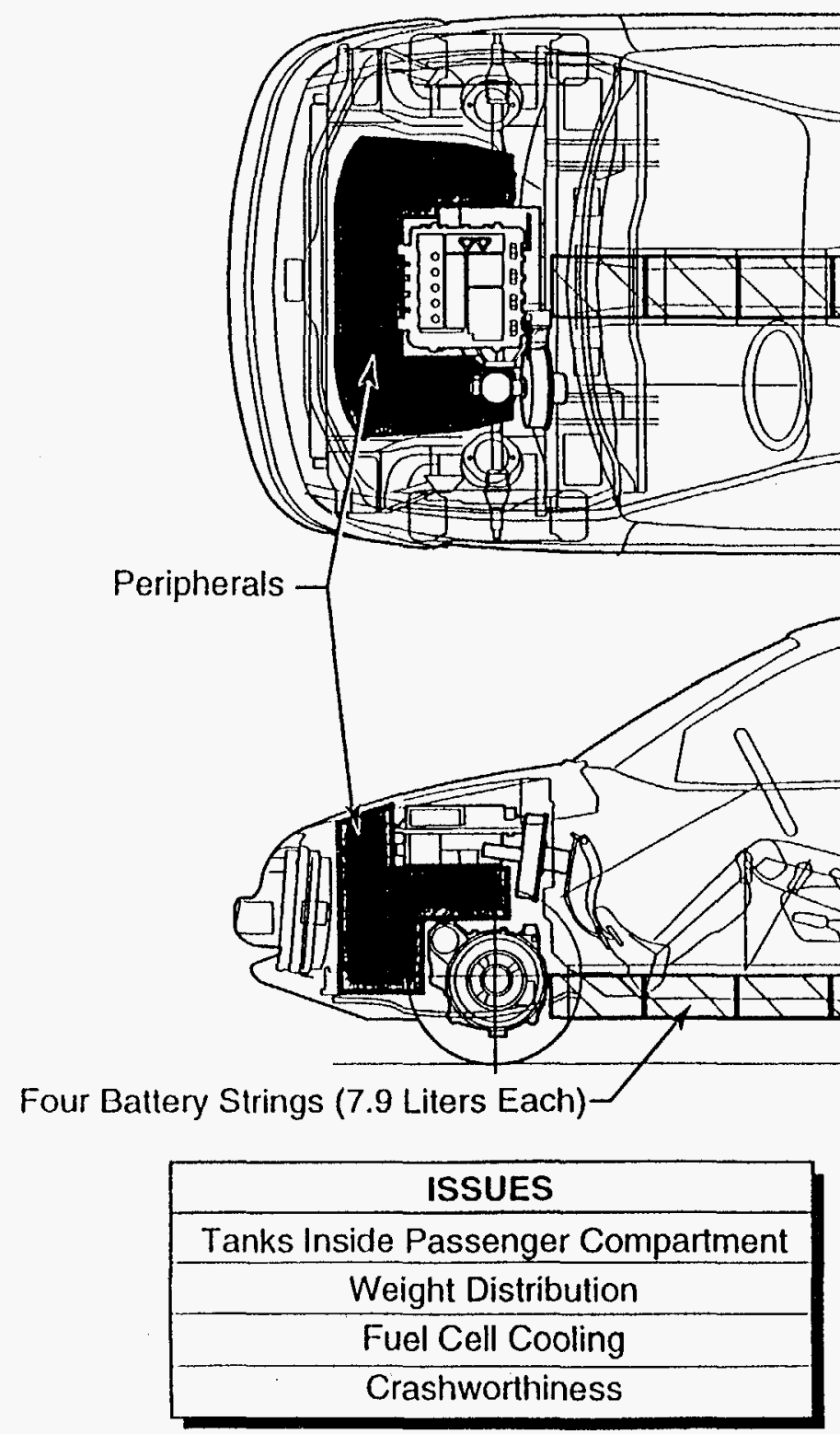

Fuel Cell Stack

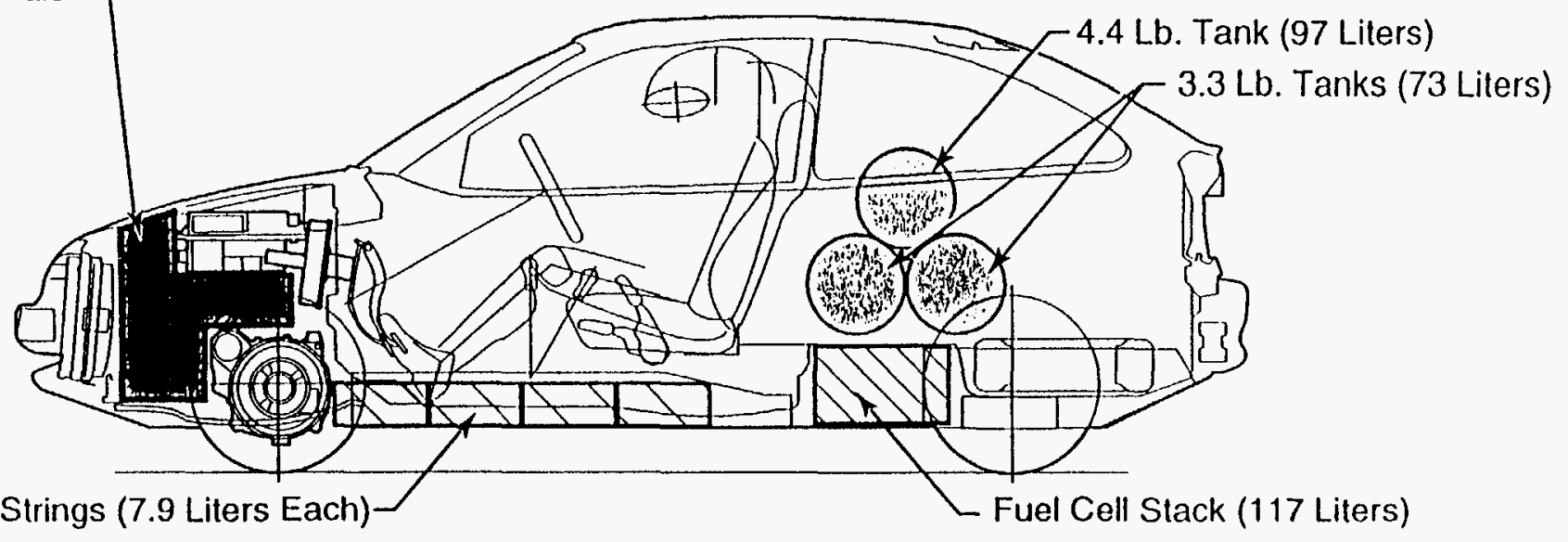

\begin{tabular}{|c|}
\hline ISSUES \\
\hline Tanks Inside Passenger Compartment \\
\hline Weight Distribution \\
\hline Fuel Cell Cooling \\
\hline Crashworthiness \\
\hline
\end{tabular}

PACKAGE VOLUMES

Fuel Cell/Peripheral Volume: 117 Liters $(7,137 \mathrm{cu}$. in.) Electric Motor Size: $\quad 56 \mathrm{~kW}(75 \mathrm{hp})$

$\mathrm{H}_{2}$ Tank Volume: $\quad 243$ Liters(11 lbs.)

Figure 5. 


\subsection{AIV Sable}

In the previous AIV Sable pure fuel cell vehicle configurations, several component arrangement schemes were demonstrated. For this exercise, only one augmented fuel cell arrangement is demonstrated for this vehicle. The overall vehicle architecture is illustrated in Figure 6.

The fuel cell power system volume was reduced to 117 liters compared to 234 liters for the pure fuel cell vehicle due to the reduction in the net fuel cell power output requirement from $80 \mathrm{~kW}$ to $40 \mathrm{~kW}$ for the battery augmented system. The cells are packaged under the front floor in the tunnel area between the occupants. Due to the projected size of the fuel cell stack, sheet metal modifications will be required to the floor and tunnel area to accommodate this package location.

The placement of the hydrogen storage tanks will be in the existing luggage compartment. For this study, the diameters of the four storage tanks were made common and only the length of the tank is varied. As with the pure fuel cell vehicle, the tank placement in the trunk will preclude that area from being used for storage. Because of the packaging inefficiency of four smaller tanks vs. two larger tanks, the distance from the rear bumper to the first hydrogen storage tank may cause an issue with rear end crashworthiness.

The five JCI Bolder batteries are packaged under the rear floor pan just ahead of the rear axle. This placement will help keep the bulk of the component weight between the front and rear wheels, thus providing better weight distribution. As with the pure fuel cell vehicle, the electric motor and controllers are located under the hood in the existing engine compartment. 


\section{AIV SABLE AUGMENTED FUEL CELL PACKAGE}

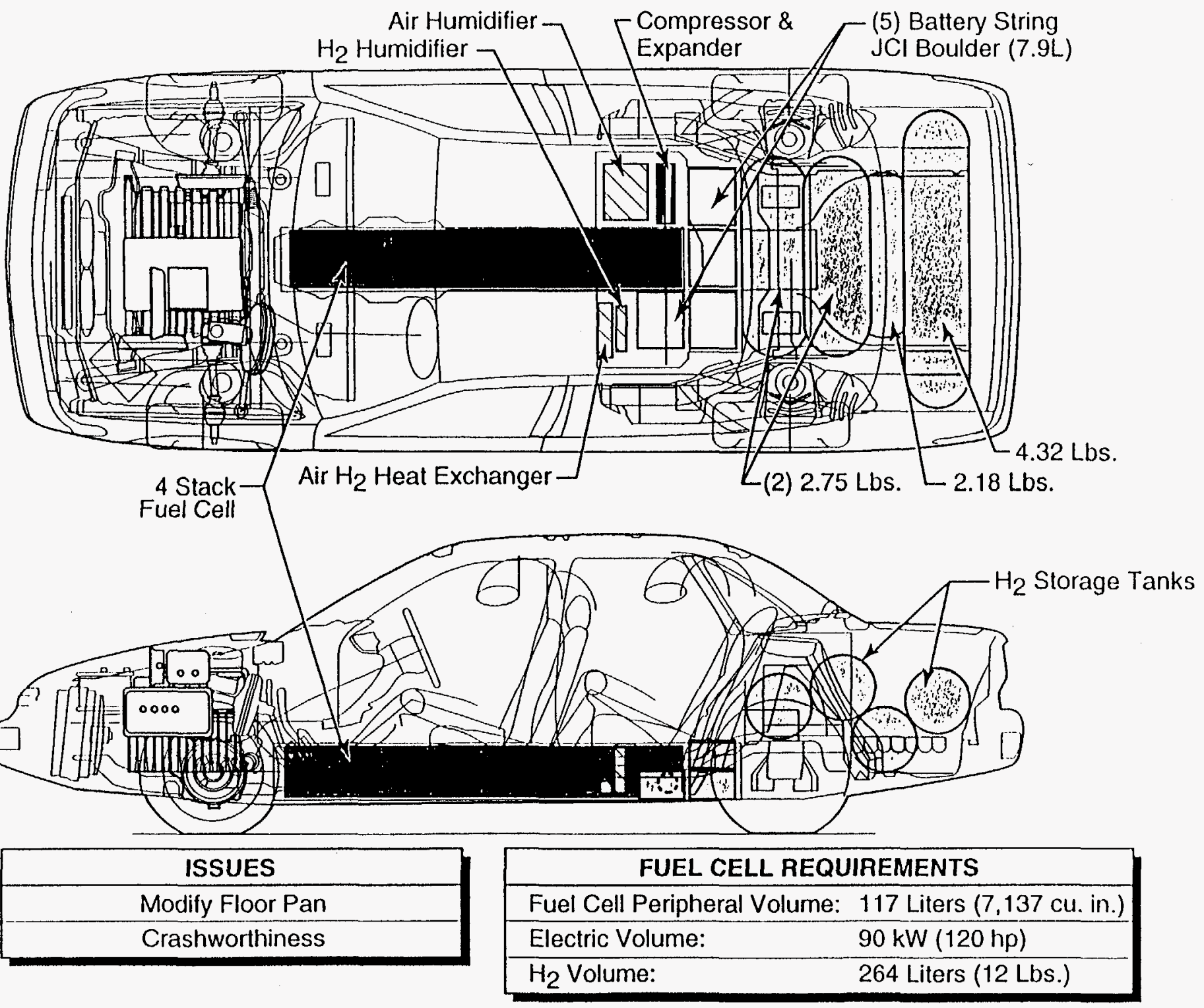

Figure 6. 


\subsection{E-150 Econoline Van}

The overall vehicle component configuration remains very similar to the pure fuel cell vehicle. Figure 7 illustrates the overall vehicle architecture.

The fuel cell power system volume was reduced to 202 liters compared to 327 liters for the pure fuel cell vehicle due to the reduction in the net fuel cell power output requirement from $125 \mathrm{~kW}$ to $70 \mathrm{~kW}$ for the battery augmented system. The package arrangement remained the same with all the fuel cell stacks packaged under the hood in the existing engine compartment.

The hydrogen storage tank locations will also remain the same, even though the tank diameters were changed to match that of the other vehicles.

The twelve (7.9 liters each) JCI Bolder battery strings, are packaged directly behind the fuel cell stacks, in the space between the front seat occupants in the tunnel area. All of the fuel cell, battery controllers and peripherals are packaged in the engine compartment and under the fuel cell stacks.

The results of these conceptual vehicle packaging exercises show that, both in the pure fuel cell vehicle and the battery augmented fuel cell vehicles, an Aspire size vehicle loses the rear seats and trunk space, an AIV Sable size vehicle relinquishes most of the trunk space, and an Econoline size vehicle retains all seats and luggage space. This conceptual vehicle packaging exercise was carried out using current production vehicle models and sizes. 


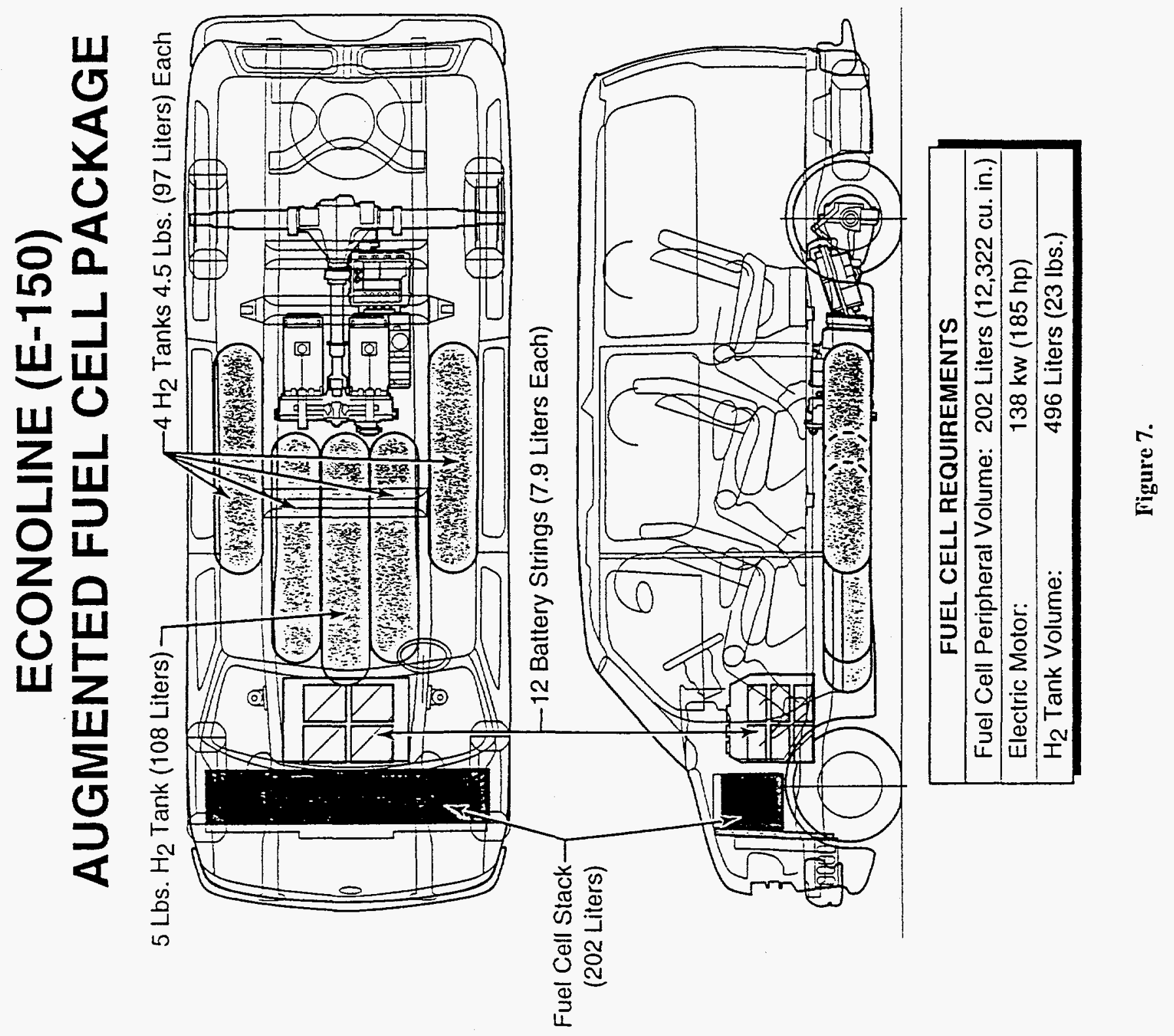




\subsection{Fuel Cell System Cost Competitiveness}

In order for direct $\mathrm{H}_{2}$ fuel cell vehicles (FCV) to be widely accepted in the marketplace, they will need to be cost-competitive with other propulsion system options of equivalent performance. The ultimate goal for FCVs is capital cost parity and life-cycle cost (LCC) superiority compared to internal combustion engine vehicles while simultaneously providing superior environmental performance and reducing foreign fuel dependence. These cost goals are ambitious, particularly since IC engine drivetrains will continually improve in cost and performance.

While FCV cost parity or superiority may not be achieved until well into the next century, the FCV may still enter the market earlier to meet strict environmental regulations such as the California Zero Emission Vehicle (ZEV) mandate. In this case, the FCV would need to be cost competitive with a battery-powered electric vehicle (BPEV) instead of a gasoline-ICE. Consumers might then choose a $\mathrm{H}_{2} \mathrm{FCV}$ with full range and acceleration capabilities over a BPEV.

The results presented in this report are preliminary capital cost estimates for the entire PEM fuel cell power system (fuel cell stack, air compressor, hydrogen management, humidifiers, radiators, etc.). In the future, detailed capital cost and life cycle cost estimates for the entire FCV drivetrain (fuel cell stack and its peripheral systems, radiator, traction motor, controller, gearbox, peak power augmentation device if applicable, and fuel system) will be prepared for comparison with the corresponding costs of the ICE drivetrain.

\subsection{Costing Approach}

As a preliminary step towards assessing FCV cost competitiveness, Ford has conducted a preliminary capital cost estimate of the direct $\mathrm{H}_{2} \mathrm{FCV}$ power system. The cost estimates are based on a broad range of proven generic component technologies and manufacturing approaches rather than specific company-proprietary techniques. Thus the intent and the result is a noncompany specific cost estimate that reflects realistic materials selection, manufacturing processes, and business pricing practices. Because the stack is the focus of the overall program, the highest cost component, and the key enabling technology of the FCV, it was chosen as the first system component for detailed costing. Thus, the cost results reflect a detailed costing of the fuel cell stacks but a less rigorous costing of the stack peripheral systems. Detailed costing of all components will be conducted and the results presented in a later report. Furthermore, only the results of the preliminary cost estimates are presented here with the details of the study conveyed in a separate costing report.

The costing methodology considers each major subassembly of the power system. The likely materials of construction and manufacturing processes are chosen based on the requirements of each subassembly, the current practice within the field, the current practice in related or allied fields, and the feasible pathways afforded by current manufacturing engineering technology. Based on Ford's corporate experience and on the popular costing methods developed by Boothroyd and Dewhurst, costs for various production operations are projected, and are added to 
the materials cost to arrive at a basic variable cost per unit produced. This cost is multiplied by a factor to reflect scrap costs, general and administrative costs (G\&A), profit and research and development costs (R\&D). For parts manufactured in-house, this factor is $22 \%$; for parts purchased from suppliers, the factor is $15 \%$. In addition to the above cost increases, a contingency cost of $10 \%$ is added to the power system estimate to reflect the cost uncertainty of vehicles not yet in production.

The notional fuel cell stack designs used here are based on two fundamental engineering concepts: design for manufacturing and assembly, and high manufacturing rate processes. Design for manufacturing and assembly (DFMA) is an engineering design concept which suggests tailoring the component design for ease of manufacturing and assembly. Parts count reduction is key to DFMA since, in general, the fewer parts there are in a system, the cheaper and quicker it will be to put them together. This seemingly simple philosophy has been proven extraordinarily powerful by numerous U.S. companies, often resulting in 30-70\% cost savings through redesign of existing products. As applied to fuel cell stack design, considerable effort has been expended to combine functionality to minimize the total number of stack parts, and to ensure that the resulting parts are both inexpensive to manufacture and easy to assemble.

The second concept which dominates the notional fuel cell stack design is design for high rate manufacturing. All materials, manufacturing, and assembly procedures are based on very high manufacturing rates $(500,000$ vehicles per year) consistent with a mature hydrogen FCV economy. Because this rate of production is much higher than that employed currently, techniques such as injection molding and automatic assembly are economically attractive. Because the fuel cells contain many repeating elements, high-volume techniques may be employed at relatively low total production rates. This means that fuel cells should reach the calculated manufacturing costs at much lower production rates than other technologies.

The detailed stack cost estimate is based on the packaging of two adjacent fuel cell stacks into a single unit called an Integrated Stack Package (ISP) as shown in Figure 8. An ISP system design was chosen to allow use of a common air manifold, thereby reducing parts count, and to allow a single fuel cell stack assembly for integration into the vehicle. The ISP contains 420 active cells of $350 \mathrm{~cm}^{2}$ active area and contains 210 cooling cells. The stack's physical parameters and thus cost are fixed but system output power will vary with overall stack electrochemical performance. As are discussed later, the ISP produces $70 \mathrm{~kW}$ gross power when operating at nominal conditions of $3 \mathrm{~atm}$ reactant gas pressure and $1,076 \mathrm{~mA} / \mathrm{cm}^{2}$ at 0.6 volts $/ \mathrm{cell}$,

To illustrate the costing approach, a sample stack costing breakdown is shown in Table 6. Each element of the stack is individually considered. Material cost for each element is computed based on the element's size, weight, and fabrication method. Manufacturing cost is computed based on each step in the fabrication process (stamping, shearing, casting, injection molding, etc.) Material cost is added to manufacturing cost and the sum marked up the appropriate percentage depending on whether the element was made in-house or purchased from outside vendors. The decision to make or purchase an element is based predominately on achieving the lowest cost. Piece part cost is multiplied by the number of pieces and summed for the entire stack to arrive at a total stack manufactured cost. 


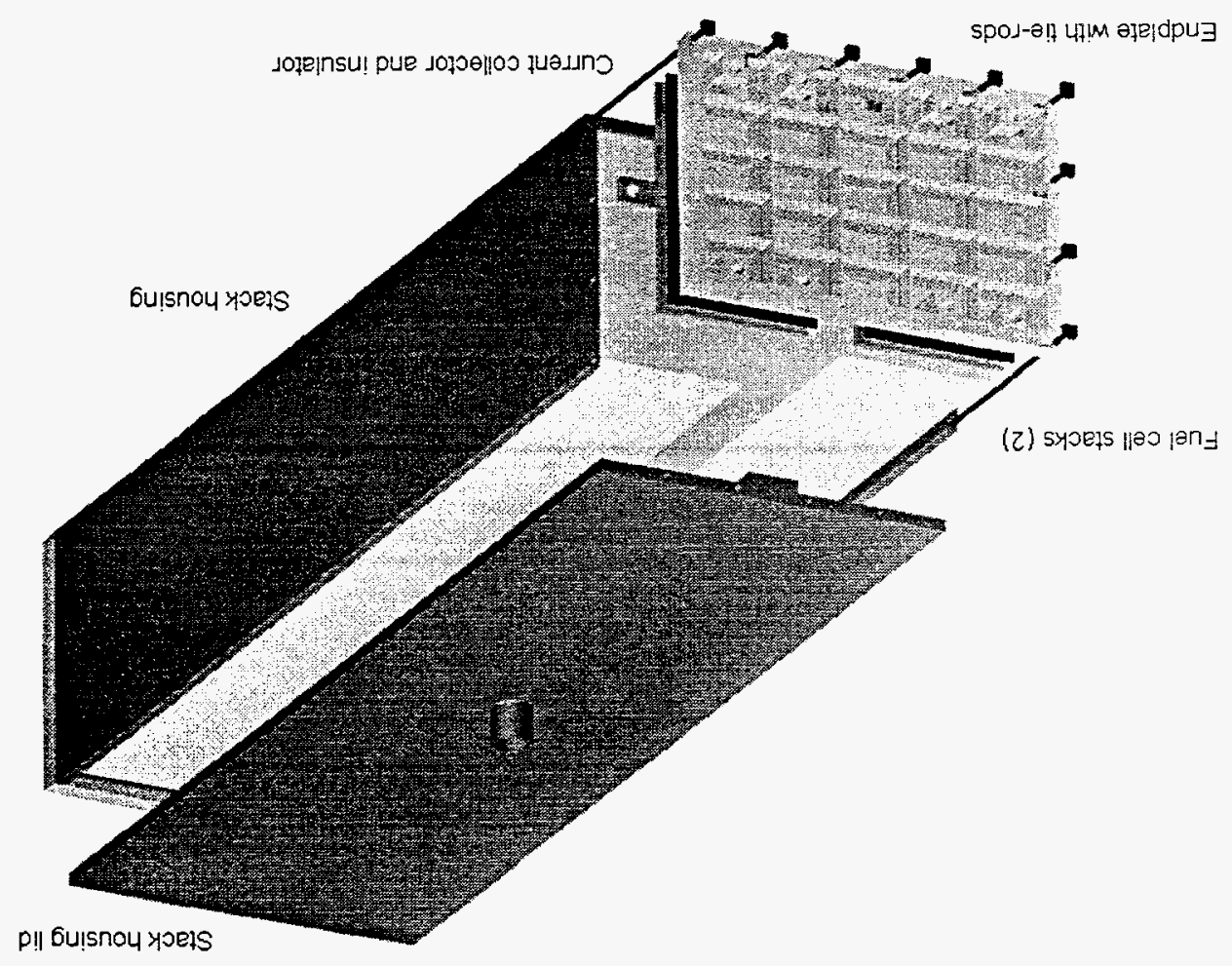

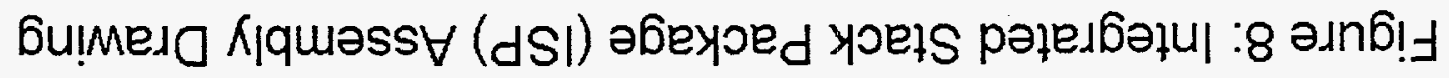


Table 6

Example of Detailed Cost Worksheet

\begin{tabular}{|c|c|c|c|c|c|c|c|c|c|c|c|c|c|}
\hline Assembly & $\begin{array}{c}\text { Make / } \\
\text { Buy }\end{array}$ & Part & Usage & Material & $\begin{array}{l}\text { spec. } \\
\text { grav. }\end{array}$ & $\begin{array}{l}\text { Mass } \\
(\mathrm{lbm})\end{array}$ & $\begin{array}{c}\text { Mat'l Cost } \\
(\$ / / b)\end{array}$ & $\begin{array}{l}\text { Matl Cost } \\
\text { (\$/unit) }\end{array}$ & $\begin{array}{l}\text { Man'f Cost } \\
\text { (\$/unit) }\end{array}$ & $\begin{array}{c}\text { Tot. Mass } \\
\text { (lbm) }\end{array}$ & $\begin{array}{c}\text { Tot. mat'l } \\
\text { Cost }(\$)\end{array}$ & $\begin{array}{l}\text { Tot. Manf. } \\
\text { Cost }(\$)\end{array}$ & $\begin{array}{c}\text { Total Marked-up } \\
\text { Cost }(\$) \\
\end{array}$ \\
\hline $\begin{array}{l}\text { Bipolar } \\
\text { Plate Assy. }\end{array}$ & $\mathrm{B}$ & Separator / Flowfield & 420 & $\begin{array}{l}\text { Carbon-fibcr } \\
\text { Polypropylene } \\
\text { carbon black }\end{array}$ & & $\begin{array}{l}0.0338 \\
0.0338 \\
0.045\end{array}$ & $\begin{array}{l}\$ 5.00 \\
\$ 0.53 \\
\$ 1.00\end{array}$ & $\begin{array}{l}\$ 0.17 \\
\$ 0.02 \\
\$ 0.05\end{array}$ & $\$ 0.10$ & 47.25 & $\$ 97.29$ & $\$ 42.00$ & $\$ 195.42$ \\
\hline Cooler Plates & B & Separator/Flowfield & 210 & $\begin{array}{l}\text { Carbon-fiber } \\
\text { Polypropylene } \\
\text { carbon black }\end{array}$ & & $\begin{array}{l}0.0338 \\
0.0338 \\
0.045\end{array}$ & $\begin{array}{l}\$ 5.00 \\
\$ 0.53 \\
\$ 1.00\end{array}$ & $\begin{array}{l}\$ 0.17 \\
\$ 0.02 \\
\$ 0.05\end{array}$ & $\$ 0.10$ & 23.63 & $\$ 48.64$ & $\$ 21.00$ & $\$ 97.71$ \\
\hline MEA & B & $\begin{array}{r}\text { on-exchange membrane } \\
\text { catalyst } \\
\text { electrodes }\end{array}$ & $\begin{array}{l}420 \\
1 \text { each } \\
1 \text { each } \\
2 \text { each }\end{array}$ & $\begin{array}{l}\text { composite polymes } \\
\text { platinum alloy } \\
\text { carbon-paper }\end{array}$ & & 0.042 & $\begin{array}{c}\$ 37.25 / \mathrm{m}^{\wedge} 2 \\
\$ 0.45 / \mathrm{m}^{\wedge} 2 \\
\$ 26.81 / \mathrm{m}^{\wedge} 2 \\
\$ 5.00 / \mathrm{m}^{\wedge} 2\end{array}$ & $\$ 1.30$ & $\$ 0.04$ & 17.64 & $\$ 545.05$ & $\$ 18.35$ & $\$ 788.91$ \\
\hline Endplates & M & & 2 & $\begin{array}{c}\text { Zinc } \\
\text { (Zamak 5) }\end{array}$ & 6.6 & 4.34 & $\$ 1.00$ & $\$ 4.34$ & $\$ 6.00$ & 8.68 & $\$ 8.68$ & $\$ 12.00$ & $\$ 25.23$ \\
\hline Plastic Insulators & B & & 2 & Polypropylene & 0.9 & 0.161 & $\$ 0.53$ & $\$ 0.09$ & $\$ 0.10$ & 0.32 & $\$ 0.17$ & $\$ 0.20$ & $\$ 0.52$ \\
\hline Current collectors (set of 3 ) & M & & 1 & aluminum & 2.7 & 4.4837 & $\$ 1.00$ & $\$ 4.48$ & $\$ 3.00$ & 4.48 & $\$ 4.48$ & $\$ 3.00$ & $\$ 9.13$ \\
\hline Plastic Housing (two-part) & B & & 1 & Polypropylene & 0.9 & 10 & $\$ 0.53$ & $\$ 5.30$ & $\$ 15.00$ & 10.00 & $\$ 5.30$ & $\$ 15.00$ & $\$ 28.48$ \\
\hline Tie bolts & B & & 16 & S.S. & 8 & 0.5 & $\$ 2.00$ each & $\$ 2.00$ & & 8.00 & $\$ 32.00$ & & $\$ 44.90$ \\
\hline
\end{tabular}

420 active cells of $258 \mathrm{~cm}^{\wedge} 2$ per cell. Cell total area of approximately $350 \mathrm{~cm}^{\wedge} 2$. Membrane extends to full cell area to prevent electrical short-circuiting. Membrane is catalyzed in strips along the long axis of the cell. Membrane catalyst loading of $0.25 \mathrm{mg} \mathrm{P} / \mathrm{cm}^{\wedge} 2$ total of anode and cathode. 
The approach for estimating assembly cost approach is illustrated in Table 7. Total stack cost per gross $\mathrm{kW}$ is determined by summing total stack manufactured cost and stack assembly cost, multiplying by 1.1 to incorporate a $10 \%$ cost contingency, and then dividing by the stack gross power output.

Table 7

Integrated Stack Package (ISP) Assembly Costs

Primary assembly (MEA-bipolar plate)

\begin{tabular}{|c|l}
\hline no & separate flowfields? \\
2 & number of active cells per cooling cell \\
18 & width between centers on conveyorized assembly line (inches) \\
4 & conveyor width (\# of fixtures) \\
20 & line speed (feet per minute) \\
53 & parts per minute \\
$\$ 4.00$ & line cost per minute $(\$ / \mathrm{min})$ \\
$\$ 0.075$ & assembly cost per part \\
\hline
\end{tabular}

Total cellstack assembly costs

420 number of active cells

210 number of cooler cells

630 total number of parts per stack

$\$ 47.25$ total cellstack assembly cost $=\#$ of parts $\mathrm{x}$ cost per part

Assembly times and costs for carousel assembly of cellstacks into finished I time (minutes $\cos$ (\$/stack) operation

\begin{tabular}{|c|l|l|}
\hline 0.5 & $\$ 0.50$ & load housing onto carousel \\
1 & $\$ 1.00$ & load cellstacks into fixturized housing \\
0.5 & $\$ 0.50$ & place housing lid \\
0.5 & $\$ 0.50$ & place 3 conductor plates \\
0.5 & $\$ 0.50$ & place two insulator plates \\
0.5 & $\$ 0.50$ & place two endplates \\
2 & $\$ 2.00$ & place sixteen tie rods \\
0.5 & $\$ 0.50$ & secure \\
0.5 & $\$ 0.50$ & miscellaneous \\
0.5 & $\$ 0.50$ & inspect \\
\hline 7 & $\$ 7.00$ & Total \\
\hline
\end{tabular}

$\$ 3.00$ leak test stack (3 minutes@ @1.00/min)

\begin{tabular}{l|l}
$\$ 57.25$ & Total ISP assembly costs before markup \\
$\$ 69.85$ & Total ISP assembly costs after markup
\end{tabular} 


\subsection{Fuel Cell Power System Options}

The FCV drivetrain is composed of either five (pure fuel cell system) or six (peak power augmented fuel cell system) major subsystems: (1) the fuel cell power system (fuel cell stack and all its related gas and water management ancillaries including electronic power system control); (2) the thermal management system (radiator and water pump); (3) the fuel storage system $\left(\mathrm{H}_{2}\right.$ tank and fuel metering device); (4) the electric drive system (electric motor and its controller); (5) the transmission system (gearbox and half-shafts); and, if required, (6) peak power augmentation system (battery, flywheel or ultracapacitor). These subsystems constitute the FCV drivetrain and perform the identical function as the ICE drivetrain composed of the ICE, electronic engine control unit, radiator, gasoline tank and pump, exhaust system and catalytic converter, and transmission, differential and half-shafts.

Within the fuel cell power system, multiple fuel cell power system options exist. The most significant option is pressurized vs. unpressurized stack operation. Pressurized operation generally results in higher stack electrochemical performance but at a penalty of added air compressor weight, complexity, cost, and parasitic power draw. Conversely, low pressure or near ambient pressure stack operation generally provides greater system simplicity and lower parasitic power loads but at a penalty of lower electrochemical performance and a corresponding increase in stack size and cost for a given power output. The low pressure system would include a low pressure air blower to force air through the stack at an appropriate velocity and mass flow. Only pressurized ( $3 \mathrm{~atm}$ ) stack operating pressures are examined in this report. A careful analysis examining the manufacturing and system costs of ambient pressure systems is worthy of a separate detailed report.

The fuel cell stack is the heart of the power system and consequently received the most detailed attention in this cost examination. Review of currently available fuel cell designs indicates that a broad range of mechanical stack designs can be employed to achieve good electrochemical performance. Since most of these approaches achieve or are projected to achieve equivalent performance, the exact methodology chosen for future production should be driven by cost to achieve a given level of net performance ( $\mathrm{kW} /$ weight, $\mathrm{kW} /$ volume). Multiple stack construction approaches were examined since the lowest cost technique is not obvious.

Variations in both the overall architecture of the fuel cell stack and the materials of construction of the stack were analyzed. Architecture refers to the exact makeup of the repeating elements in the stack. Thus, stack architecture encompasses the ratio of active cells to cooling cells and the presence or absence of internal humidification. Within any given architecture, it is assumed that the repeat elements may be constructed from three types of material in four specific formats. The three materials are thin 316 stainless steel sheet metal, solid amorphous carbon, and carbonpolymer composite. The four formats are summarized below and in Table 8. 
Table 8

Plausible Bipolar Plate Constructions

\begin{tabular}{|c|c|c|c|c|}
\hline Attribute & $\begin{array}{l}\text { Unitized } \\
\text { Metallic }\end{array}$ & $\begin{array}{l}\text { Three-Piece } \\
\text { Metallic }\end{array}$ & $\begin{array}{l}\text { Solid } \\
\text { Carbon }\end{array}$ & $\begin{array}{l}\text { Carbon- } \\
\text { Polymer } \\
\text { Composite }\end{array}$ \\
\hline \multirow{2}{*}{$\begin{array}{l}\text { Material } \\
\text { Processing }\end{array}$} & Stainless Steel & Stainless Steel & $\begin{array}{l}\text { Carbon } \\
\text { Black/Pitch }\end{array}$ & $\begin{array}{l}\text { Carbon } \\
\text { Fiber/Polymer }\end{array}$ \\
\hline & $\begin{array}{l}\text { 1) Stamp from } \\
\text { coil, forming 3-D } \\
\text { surface, } \\
\text { 2)pierce/blanking } \\
\text { to form } \\
\text { manifolds and } \\
\text { exterior } \\
\text { dimensions } \\
\text { 3)Insert-mold } \\
\text { elastomer gaskets } \\
\text { or attach separate } \\
\text { gaskets }\end{array}$ & $\begin{array}{l}\text { 1) Pierce/blank } \\
\text { separator } \\
\text { 2) roll-form } \\
\text { anode and } \\
\text { cathode flow- } \\
\text { fields, shear to } \\
\text { length } \\
\text { 4) Insert-mold } \\
\text { elastomer gaskets } \\
\text { or attach separate } \\
\text { gaskets }\end{array}$ & $\begin{array}{l}\text { 1)Injection mold } \\
\text { "green" plate } \\
\text { 2)carbonize plate } \\
\text { in oven } \\
\text { 3)surface-grind } \\
\text { plate }\end{array}$ & $\begin{array}{l}\text { 1)Injection mold } \\
\text { plate }\end{array}$ \\
\hline
\end{tabular}

1) Unitized metallic: a thin stainless steel sheet is processed through a progressive die set to yield a single part which serves as both a gas barrier and two flow fields.

2) Three-piece metallic: the repeat unit consists of two perforated stainless steel flow fields and a single non-perforated stainless steel gas barrier.

3) Solid amorphous carbon: the repeat part is a solid, non-porous carbon plate with flow field molded into either side.

4) Carbon-polymer composite: This approach employs an electrically-conductive carbonpolymer composite of three constituents: 1) a low-cost thermoplastic binder, 2) milled carbon power and 3) chopped carbon fibers. These final additives are desirable to improve the conductivity and physical properties of the finished parts. The single plate serves as both gas barrier and flow field.

\subsection{Cost Modeling Assumptions}

Fuel cell stack cost is estimated using the costing methodology described above for each of the bipolar plate constructions described in Table 8. The methodology basically consists of applying appropriate mark-up factors to the material, manufacturing, and assembly cost of the stack. While a complete statement of the cost assumptions is beyond the scope of this report, the component manufacturing and assembly steps are described below to convey the approximate 
level of detail and plausibility of the cost estimates without becoming bogged down in details. Additional key assumptions are included as needed.

1) Unitized metal repeat parts: Bipolar plate assembly is constructed as follows: a continuous coil of 316 stainless steel of about 127 micron ( 0.005 inch) is fed to a progressive sheet metal die which embosses the flow fields, pierces the manifold openings, then blanks the finished separator / flowfield. This piece is then placed in an insertion molding machine which injection molds a polymer gasket / bearing surface / manifold in four separate regions on two sides of the plate. Alternatively, the gaskets are molded separately and heat-staked into place.

2) Three-piece metallic repeat parts: Bipolar plate assembly is constructed as follows: a continuous coil of 316 stainless steel of about 50.8 micron $(0.002$ inch) is fed to a progressive sheet metal die which pierces the flow manifolds, then blanks or parts-off the finished separator. The flowfields are formed separately from similar coils of stainless steel in a roll-forming machine employing offset gears to form the flow field pattern or in a conventional stamping operation. The resulting formed metal is sheared to length. The separator plate is then placed in an insertion molding machine which injection molds a polymer gasket / bearing surface / manifold in four separate regions on two sides of the plate. Alternatively, the gaskets are molded separately and heat-staked into place.

3) Solid Carbon repeat parts: Anode and cathode flow fields are manufactured as follows: a "green" preform is injection molded from pitch / coke, the preforms are carbonized in a 1000 degree $\mathrm{C}$ oven for approximately 45 minutes, activated by cooling with carbon dioxide for 15 minutes, then ground flat on a centerless grinder.

4) Carbon-Polymer Composite repeat parts: Bipolar plates are manufactured as follows: low-cost pitch-based chopped carbon fiber is mixed with both a polypropylene matrix polymer and carbon powder and injection molded.

Each stack architecture is constructed differently. The approach addressed here utilizes two active cells for each cooling cell. This allows each cell to be in intimate contact with a cooling cell, while reducing parts count when compared to approaches which employ a cooler for every active cell. It is assumed that the molded repeat parts and unitized metallic repeat parts require only the insertion of a unique bipolar plate into the stack while the three-piece metallic requires the insertion of two unique gas barriers as well as an extra flow field. Further, the metallic fuel cells utilize electrically non-conductive gaskets, which allows minimization of the required membrane electrode assembly (MEA) area. The solid carbon and carbon-polymer composite repeat parts require greater MEA usage because the MEA must extend to the outer edges of the stack in order to avoid short circuiting the stack electrically. The other key components and items impacting the fuel cell power system cost are described below.

Membrane Electrode Assembly (MEA): Common to all four bipolar plate constructions is the assumption of a unitized MEA consisting of a very thin ionomer $/$ expanded polytetrafluoroethylene (PTFE) composite membrane, catalyst / ionomer ink coatings, and carbon paper diffusion electrodes. In order to develop an accurate cost prediction for the MEAs, a 
notional production process was developed from information available in the open literature. This process is shown schematically in Figure 9. This process is continuous, and employs machinery which is common to the converting industry. The cost for the bare ion-exchange membrane predicted from the process is only $\$ 1.28$ per square meter while previously projected costs were on the order of $\$ 580$ per square meter. This cost is still much higher than that for many commercially-available polymer films, reflecting the inherently expensive materials and slow processing inherent to fluorinated polymer ion-exchange membranes.

Catalyst Loading: A total catalyst loading (both electrodes) of $0.25 \mathrm{mg} \mathrm{Pt} / \mathrm{cm}^{2}$ and a platinum cost of $\$ 421 /$ troy ounce were assumed for all stacks. It is assumed that the catalyst is applied continuously in strips along the long axis of the MEA. This should be readily achievable using conventional converting machinery, and represents a considerable savings over the uniform application of catalyst across the MEA. This tradeoff is discussed in greater detail in the full costing report.

Endplates: The endplates are hard, anodized diecasts of aluminum alloy because of its ease of castability and high stiffness to weight ratio.

Manifolds: It is assumed that many of the manifolds are formed into the repeat parts. The remaining manifolding and protection from the external environment are provided by a large injection-molded polymer container.

Tie-rods: Stainless steel or aluminum tie rods are run outside of the polymer container to both compress the finished stack and to lend rigidity to the stack during assembly.

Stack Electrochemical Performance: Pressurized stacks were assumed to operate at 3 atm with electrochemical performance parametrically examined from $650-1500 \mathrm{~mA} / \mathrm{cm}^{2}$ at $0.6 \mathrm{~V} / \mathrm{cell}$. A nominal stack performance point of $1,076 \mathrm{~mA} / \mathrm{cm}^{2}$ at $0.6 \mathrm{~V} / \mathrm{cell}$ is selected as representative of currently achievable stack performance. However, future electrode and membrane optimization may significantly increase stack performance.

Humidifiers: There is doubt within the fuel cell community whether future generation fuel cell stacks will require air and hydrogen gas humidification. Humidification is generally required to maintain membrane moisture and thus membrane conductivity. As future MEAs evolve and the thickness and water content of the polymer electrolyte decreases, it is increasingly feasible to maintain adequate anode side moisture through cathode side water production and diffusion across the membrane. Consequently, hydrogen stream humidification may not be required at all and air stream humidification requirements may be quite modest ( $<20 \%$ relative humidity). Given these potentially limited humidification requirements, power system humidifiers are modeled as external to the stack: compact water injection units spray heated humidification water into the air stream prior to introduction to the fuel cell stack. The water injectors are directly analogous to ICE fuel injectors. The humidification chamber is jacketed by cooling water to maintain the humidifier air stream at approximately stack operating temperature. A small water pump is needed to pressurize water for the injector. 
Figure 9

Proposed Membrane Electrode Assembly Integrated Process Train (Wet Process)

Schematic View, Not to Scale

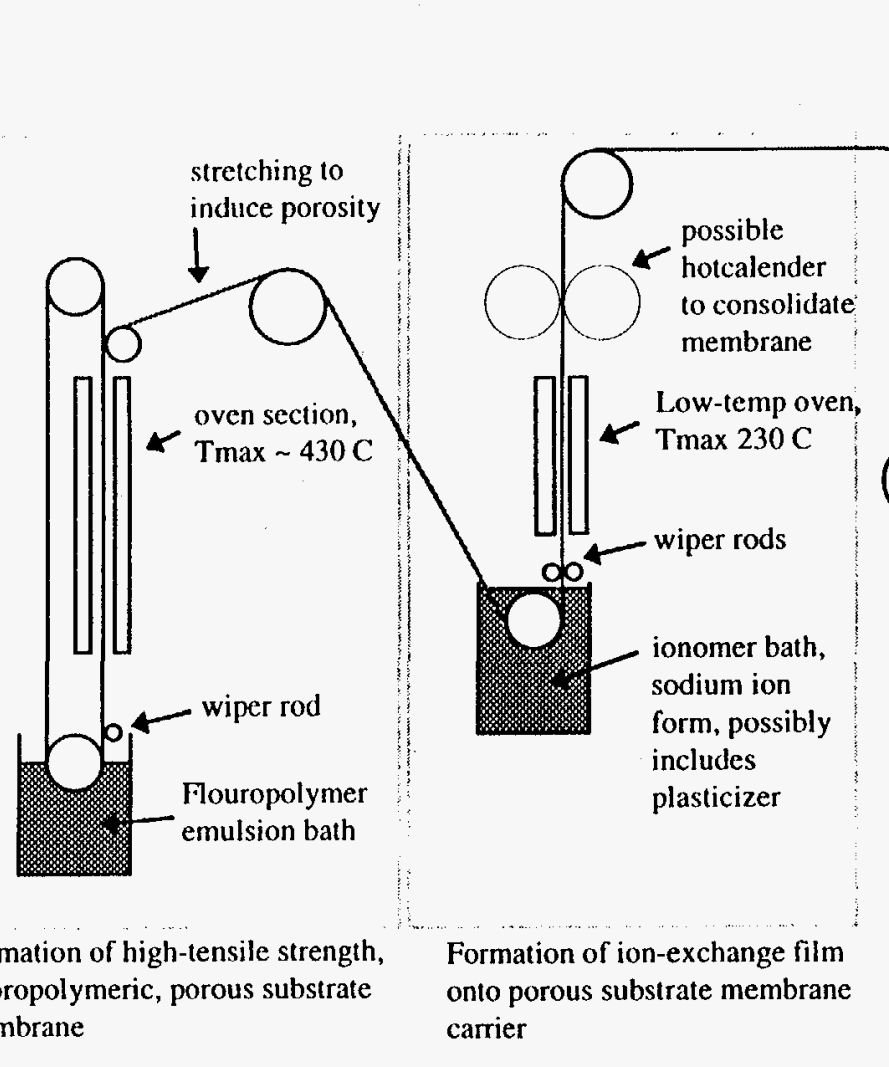
fluoropolymeric, porous substrate membrane onto porous substrate membrane carrier

Initial bath casting onto a continuous, high-temperature polymer belt. Feed rate limited to $10-30 \mathrm{fpm}$ by size of practical oven. Substrate membrane is peeled from the continuous belt then stretched. Stretching of partially crystallized fluoropolymer $(50 \%-70 \%)$ along the axis of the substrate membrane with or without additional heating. Stretching will increase the linear feed rate by a factor of 2 or greater, and result in a highly-porous substrate membrane of controlled thickness. Ionomer emulsion or solution is cast onto the web then dried and cured in an oven or hot-calendered to ensure proper consolidation. Because the ionomeric material requires lower temperatures than the

fluoropolymer, high speeds should be attainable. The result is a composite ionexchange membrane with the ionomer in the sodium ion form.

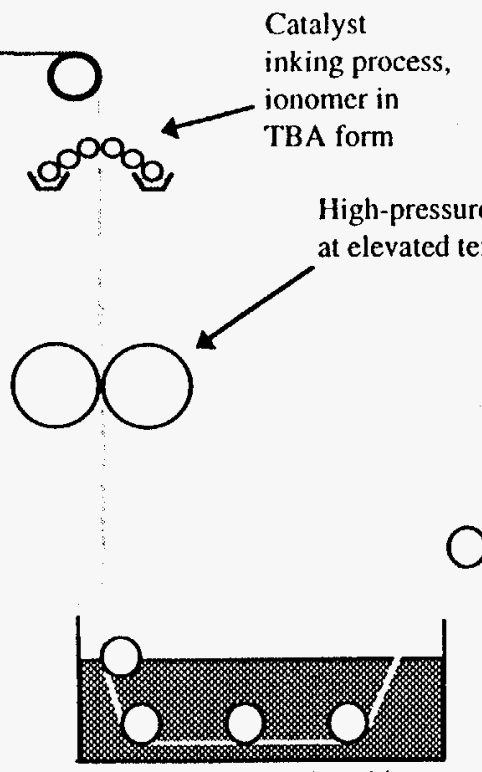

Sulphuric/Sulphonic acid bath, $\sim 10 \mathrm{~min}, 50 \mathrm{C}$ or more

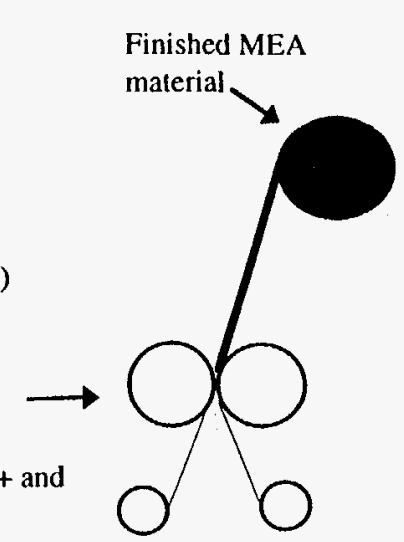

Altachment of carbon paper electrodes through hot calendering, $500 \mathrm{psig}+$ and $225 \mathrm{C}$ or more

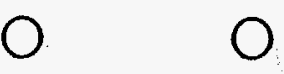

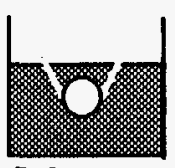

D-I water

rinse

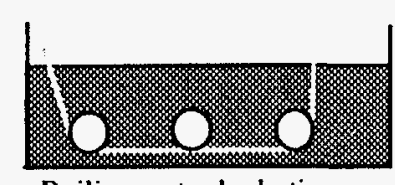

Boiling water hydration, $\sim 10 \mathrm{~min}$
Metering bars or equivalent means are employed to add the appropriate amounts of both anodic and cathodic ink in an emulsion with the tetrabutyl ammonium (TBA) form of the ionomeric material and a carrier of dimethyl sulfoxide or other appropriate material. The inked membrane is then hot-calendered at a temperature and pressure sufficient to effect proper mating between the catalysts and the membrane. The membrane is then protonated, rinsed, and hydrated. The final step is hot calendering the carbon paper electrodes to the catalyzed membrane, which might also include hydrophobic doping with a fluoropolymer. 
Detailed humidifier system costing has not been conducted but given the strong similarity to ICE fuel injectors, the cost of the entire humidification system is estimated at $\$ 75$ after markup.

Air Compression System: For pressurized stack systems a combination centrifugal air compressor and exhaust gas expansion turbine is modeled. The compressor and turbine operate on a single shaft so that the expansion power of the turbine supplies the majority of air compression power required. A small permanent magnet high speed electric motor is also mounted to the shaft to supply the power shortfall between power required and turbine power available. The compressor / expander / motor unit is expected to operate at a speed of approximately $100,000 \mathrm{rpm}$ for high efficiency and to function with a decreased compression ratio at system part power so as to stay within the compressor and turbine surge limits. The compression and turbine wheels are cast aluminum alloy requiring only modest machining. The unit is air cooled. The DOE cost target for similar devices is $\$ 200$ for a unit appropriate for a $55 \mathrm{~kW}$ gross fuel cell system. While the detailed materials, manufacturing, and assembly cost methodology described above has not yet been applied to the unit, preliminary cost estimates indicate a unit cost of $\$ 411$ after markup for a $70 \mathrm{~kW}$ gross stack output system. The more conservative projections, scaled to match stack power level, are used in the cost projections.

Hydrogen Recirculation Ejector: Since the fuel stream is pure undiluted hydrogen gas, the stack effectively functions as if it were dead-ended. However, to facilitate proper anode water management, $10 \%$ to $40 \%$ of the anode gas is assumed recirculated through the stack. This is accomplished by a small hydrogen ejector which uses the energy of high pressure $\mathrm{H}_{2}$ gas coming from onboard gaseous storage tanks to entrain and hence recycle the lower pressure gas coming out of the stack. The $\mathrm{H}_{2}$ ejector consumes no power and is estimated to cost $\$ 20$ after markup.

Deionizing Filter: To prevent electrical shorting of the stack, coolant water resistivity must be maintained at relatively high levels. The cost of a small water deionizing filter is estimated at $\$ 20$ after markup.

Electronic Engine Control (EEC) Unit: A small electronic controller unit is required to monitor and control the fuel cell power system. Detailed EEC costing has not been conducted but the cost is estimated at $\$ 200$ to match the approximate cost of ICE EEC units produced in large quantities.

Radiator System: The cost of the radiator system consisting of the radiator and small electric motor driven coolant pump is estimated at $\$ 150$ based on current mass production IC engine radiator systems. The same cost is used for both pressurized and ambient pressure system radiators since detailed costing and sizing analyses has not yet been conducted. 
Stack Assembly: Stack assembly takes place on conveyerized assembly lines using current automotive and industrial practice. Stack assembly includes several major steps:

1) assembly of the basic repeat unit (either an MEA plus flow field or an MEA plus flow fields plus cooler cell),

2) assembly of repeat units to one another,

3) placement and securing of cell stack into stack housing, placement of stack cover, insulator plates, current conductors, endplate, and tierods,

4) inspection and leak test of stack.

System Assembly: The cost of system assembly (i.e. mounting of the system peripherals to the Integrated Stack Package) is estimated at $\$ 25 /$ system based solely on analogy to internal engine assembly procedures. Detailed assembly cost estimation has not yet been conducted.

System Parasitic Loads: Fuel cell power systems will have parasitic power loads from compressors, fans, blowers, and electronic control systems. Rather than individually tabulating component power consumption, an across the board parasitic power load equal to $11 \%$ of system gross power was assessed for pressurized systems. Thus, a $3 \mathrm{~atm}$ pressurized system producing $70 \mathrm{~kW}$ gross power was assumed to generate $62 \mathrm{~kW}$ net power. The system parasitic load assumption is used only in the computation of $\$$ per $\mathrm{kW}$ net.

Contingency: To reflect the cost uncertainty of the relatively immature fuel cell technology and the lack of production experience, overall cost is marked-up an additional $10 \%$.

\subsection{Preliminary PEM Power System Cost Estimates}

The results of the detailed stack costing analysis are summarized in Table 9 and Figure 10. As described above, the costing methodology was to estimate the cost of a fixed size stack using various stack materials and flow field architectures. Consequently, a single dollar value is estimated for each construction technique. However, $\$ / \mathrm{kW}$ stack cost depends on the electrochemical performance of the stack which was parametrically varied from $390 \mathrm{~mW} / \mathrm{cm}^{2}$ to $900 \mathrm{~mW} / \mathrm{cm}^{2}$ to correspond to stack current densities from $650 \mathrm{~mA} / \mathrm{cm}^{2}$ to $1,500 \mathrm{~mA} / \mathrm{cm}^{2}$, all at 0.6 volts/cell. As seen in Figure 10, electrochemical performance of the cells has much more effect on stack $\$ / \mathrm{kW}$ than choice of stack material/cell architecture.

One surprising result of the cost analysis is that even at the relatively low catalyst loading of $0.25 \mathrm{mg} \mathrm{Pt} / \mathrm{cm}^{2}$, catalyst cost is $\$ 5-\$ 8 / \mathrm{kW}$ gross. Thus future progress in catalyst reduction may significantly reduce stack cost. In addition, manufacturing cost represents only $10 \%$ of stack cost indicating both the relative ease of plate manufacture and the potential cost sensitivity to material price changes. 
Peripheral system cost estimates are shown in Table 10 for pressurized pressure systems. The reader is once again reminded that detailed costing has not yet been conducted on the peripheral system components and that the results presented are preliminary values. Cost of the peripheral systems do not scale linearly with system output power. Consequently, care must be taken when applying the derived peripheral system $\$ / \mathrm{kW}$ values to systems much larger or much smaller than the design basis.

Table 11 and Figure 11 show overall PEM power system cost estimates for each of the four stack architectures both at the nominal electrochemical performance level ( $\$ 40-\$ 50 / \mathrm{kW}$ net at $1,076 \mathrm{~mA} / \mathrm{cm}^{2}$ at 0.6 volts/cell) and as a function of current density $\left(\$ 29-\$ 36 / \mathrm{kW}\right.$ net at $1,500 \mathrm{~mA} / \mathrm{cm}^{2}$ at 0.6 volts/cell. Carbon-polymer composite stack construction provides the lowest system cost by combining low materials cost (carbon powder, low-cost resin) with a low-cost manufacturing technique (injection molding). The other stack constructions are estimated to cost $15-25 \%$ more.

As expected, these results are only a fraction of current fuel cell stack prices of $\$ 10,000$ $\$ 20,000 / \mathrm{kW}$. However, mass produced ICE propulsion systems (engine block and peripherals, transmission, emission apparatus, etc.) currently cost approximately $\$ 20-\$ 30 / \mathrm{kW}$. Furthermore, the IC engines produce mechanical power and fuel cell systems produce electrical power. Thus the PEM power system cost is already equal to or greater than the ICE drivetrain. While drivetrain cost projections have not yet been conducted, the remaining PEM system drivetrain components can be expected to cost at least $\$ 7 / \mathrm{kW}$ based on Partnership for a New Generation Vehicle (PNGV) 2006 technical cost goals for the inverter and traction motor alone.

Table 9

Summary Fuel Cell Stack Cost Estimate

\begin{tabular}{|l|l|}
\hline $\begin{array}{l}\text { Fuel Cell Stack } \\
\text { Architecture/Plate } \\
\text { Material }\end{array}$ & $\begin{array}{l}\text { Integrated Stack Package } \\
\text { (ISP) Cost } \\
\text { (420 active cells, } \mathbf{2 5 8} \mathbf{~ c m}^{2} \\
\text { active area per cell) }\end{array}$ \\
\hline $\begin{array}{l}\text { Unitized Metal } \\
\text { Three-Piece Metal } \\
\text { Solid Carbon } \\
\text { Carbon-Polymer } \\
\text { Composite }\end{array}$ & $\begin{array}{l}\$ 1738 \\
\$ 2003 \\
\$ 1813 \\
\$ 1386\end{array}$ \\
\hline
\end{tabular}

All costs include assembly and a $10 \%$ contingency. 


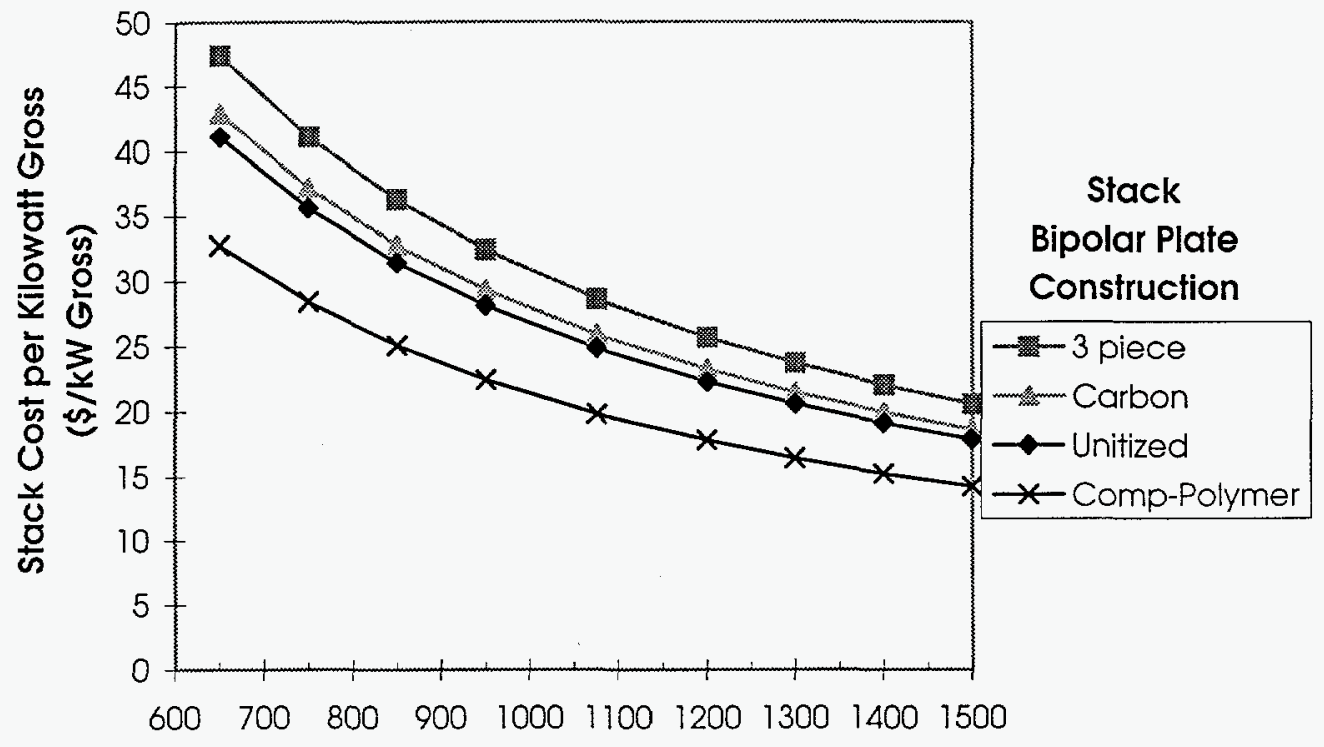

Stack Current Density $\left(\mathrm{mA} / \mathrm{cm}^{2}\right)$ at 0.6 volts/cell

Figure 10 - Stack Cost Per Gross Kilowatt

Table 10

Summary Peripheral System Cost Estimate

\begin{tabular}{|c|c|c|}
\hline Subassembly & $\begin{array}{l}\text { Approximate } \\
\text { Peripheral Systems } \\
\text { Cost } \\
\end{array}$ & $\$ / \mathbf{k W}$ gross \\
\hline \multicolumn{3}{|l|}{ Pressurized System Peripherals for } \\
\hline $70 \mathrm{~kW}$ gross Fuel Cell Stack & & \\
\hline Compressor/Expander/Motor Unit & $\$ 428$ & \\
\hline Air Humidifier Subsystem & $\$ 75$ & \\
\hline H2 Recirculation Ejector & $\$ 20$ & \\
\hline $\mathrm{EEC}$ & $\$ 200$ & \\
\hline Radiator Subsystem & $\$ 150$ & \\
\hline DI Filter & $\$ 20$ & \\
\hline Piping, Valving, Miscellaneous & $\$ 100$ & \\
\hline $10 \%$ Cost Contingency & $\$ 99$ & \\
\hline Total & $\$ 1092$ & $\$ 16 / \mathrm{kW}$ gross \\
\hline
\end{tabular}


Table 11

Summary Fuel Cell Power System Cost Estimate ( $\$ / \mathrm{kW}$ net)

\begin{tabular}{|c|c|}
\hline $\begin{array}{l}\text { Fuel Cell Stack } \\
\text { Architecture/Plate } \\
\text { Material }\end{array}$ & $\begin{array}{l}\text { Pressurized Air System } \\
\text { based on } 63 \mathrm{~kW} \text { net } \\
\text { System Power Output and } \\
646 \mathrm{~mW} / \mathrm{cm}^{2} \\
\text { Stack Performance Level } \\
\left(0.6 \mathrm{v} / \mathrm{cell}, 1,076 \mathrm{~mA} / \mathrm{cm}^{2}\right)\end{array}$ \\
\hline Unitized Metal & $\$ 46 / \mathrm{kW}$ net \\
\hline Three-Piece Metal & $\$ 50 / \mathrm{kW}$ net \\
\hline Solid Carbon & $\$ 47 / \mathrm{kW}$ net \\
\hline $\begin{array}{l}\text { Carbon-Polymer } \\
\text { Composite }\end{array}$ & $\$ 40 / \mathrm{kW}$ net \\
\hline
\end{tabular}

All costs include a $10 \%$ contingency.

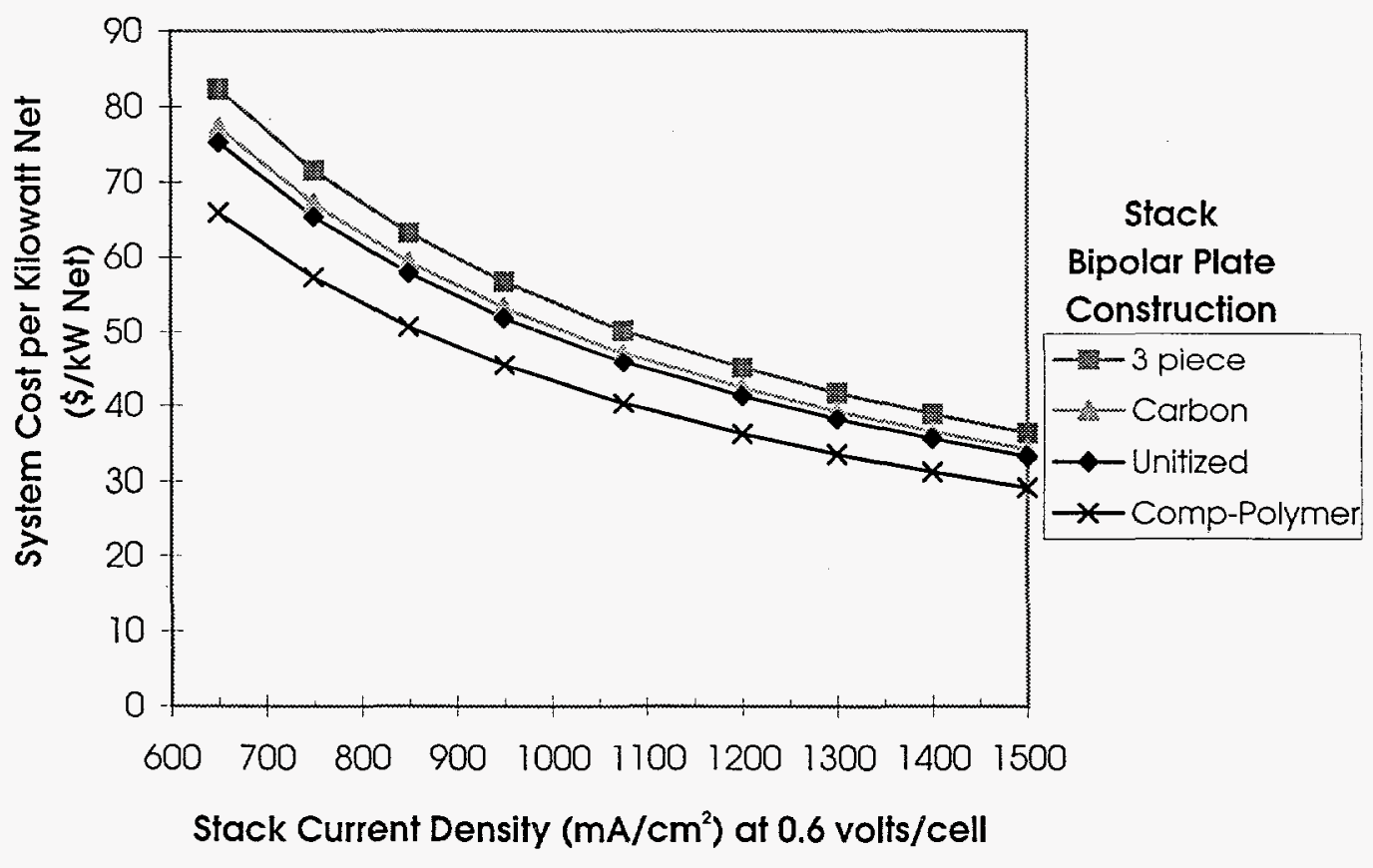

Figure 11 - System Cost Per Kilowatt Net 
Overall, these preliminary PEM power system cost estimates suggest the PEM drivetrain will not achieve cost parity with the ICE vehicle drivetrain, but it still may be cost competitive, especially after accounting for such intangibles as zero emissions. However, detailed drivetrain cost estimates have not yet been conducted. Future work will expand the detailed costing methodology to the power system peripheral systems and to the remaining drivetrain components so that a fair drivetrain-to-drivetrain cost comparison between fuel cell vehicles and ICE vehicles may be made. 


\subsection{Conclusions and Recommendations}

Analysis of the battery augmented fuel cell vehicle design shows that there are no insurmountable barriers in packaging. The results show the same restrictions as in the pure fuel cell powertrain vehicle packaging. The capability of responding to instant high power demand for start-up and acceleration is only one of the factors for using a power augmentation device. However, power augmentation will add complexity to the whole system with respect to the controller for the fuel cell and the battery system in order to avoid undesired electric interaction between the two power sources. With the progress that has been made in increasing the power density of the fuel cell stack, it is also not clear whether the weight and volume of the power augmenting battery will be equivalent to that of the fuel cell system.

The direct-hydrogen-fueled fuel cell powertrain vehicle provides the simplest system for the introduction of the fuel cell vehicle. Past experience with the $10 \mathrm{~kW}$ fuel cell stacks that were delivered in Phase I of this contract provides evidence that such a stack can provide the basic unit for a higher power fuel cell system for automotive applications. Additional studies are needed to look at the various options of battery augmentation, such as full power battery augmentation for acceleration or only partial augmentation for start-up of the fuel cell vehicle. Unless there is a clear economic benefit for battery augmentation of the fuel cell vehicle, the added technical complexity of adding a sizable battery power source to the fuel cell system favors the pure fuel cell vehicle powertrain for automotive use. In the final analysis, cost is still the deciding factor for public acceptance of a fuel cell vehicle, whether battery augmented or not. Some of the technical and economic issues have been addressed in this report and the previous report [1], providing a good foundation for future work. 


\section{References}

[1] "Preliminary Conceptual Vehicle Design Report - Pure Fuel Cell Vehicle" prepared for the United States Department of Energy, under Contract No. DE-AC02-94CE50389, February 6, 1997.

[2] Ballard Power Systems, Inc., Annual Report 1995.

[3] "Product Design for Manufacture and Assembly", J. Boothroyd, P. Dewhurst, W. Knight, Marcell Dekker Inc., New York, 1994. 